\title{
A MOTIVAÇÃO DAS DECISÕES SOBRE REVISTA NAS PRIMEIRAS DÉCADAS DOS SUPREMOS TRIBUNAIS DE JUSTIÇA NO BRASIL E EM PORTUGAL (1834-1866) ${ }^{1}$
}

\section{THE MOTIVATION OF APPEAL DECISIONS IN THE FIRST DECADES OF THE BRAZILIAN AND PORTUGUESE SUPREME COURTS OF JUSTICE (1834-1866)}

\author{
António Manuel Hespanha \\ Universidade Nova de Lisboa - NOVA - (Lisboa, Portugal) \\ Walter Guandalini Junior \\ Universidade Federal do Paraná - UFPR - (Curitiba, PR, Brasil) \\ Recebimento: 13 ago. 2019 \\ Aceitação: 3 dez. 2019
}

\begin{abstract}
Como citar este artigo / How to cite this article (informe a data atual de acesso / inform the current date of access):
HESPANHA, António Manuel; GUANDALINI JUNIOR, Walter. A motivação das decisões sobre revista nas primeiras décadas dos Supremos Tribunais de Justiça no Brasil e em Portugal (1834-1866). Revista da Faculdade de Direito UFPR, Curitiba, PR, Brasil, v. 65, n. 1, p. 185-224, jan./abr. 2020. ISSN 2236-7284. Disponível em: $<$ https://revistas.ufpr.br/direito/article/view/68498>. Acesso $\quad$ em: $30 \quad$ abr. $2020 . \quad$ DOI:
\end{abstract} http://dx.doi.org/10.5380/rfdufpr.v65i1.68498.

\section{RESUMO}

No presente estudo realiza-se uma análise comparativa das motivações empregadas nas decisões proferidas em recursos de revista pelos Supremos Tribunais de Justiça do Brasil e de Portugal, na segunda metade do século XIX. Para isso se contextualiza historicamente o entendimento doutrinário predominante nas culturas jurídicas dos dois países acerca do dever de motivação das sentenças, verificando-se que na sociedade do antigo regime o dever de motivação era considerado instrumento acessório, necessário somente para a preservação do direito régio. Em seguida, emprega-se o método de análise de conteúdo para avaliar suas especificidades quanto às características dos recursos (origem, matéria, fundamentação) e das partes recorrentes (gênero, estatuto social). Foram identificadas correlações entre as características dos recorrentes, as matérias recorridas e os tipos de fundamentação empregados, e ao final concluiu-se que as decisões proferidas no período indicam tratar-se de uma jurisprudência de transição, a meio caminho entre a fundamentação pluralista do antigo regime e a fundamentação legalista típica da modernidade.

\section{PALAVRAS-CHAVE}

Motivação das decisões. Recurso de revista. Supremo Tribunal de Justiça. Brasil. Portugal.

\begin{abstract}
In this study, a comparative analysis of the motivations in appeal decisions by the Supreme Courts of Justice in Brazil and Portugal in the second half of the nineteenth century is carried out. It begins by historically contextualizing the doctrinal understanding, in the legal cultures of both countries, about

1 Este artigo, escrito em coautoria com o professor Walter Guandalini Junior, é provavelmente um dos últimos trabalhos desta natureza, se não o último, do saudoso professor Hespanha, nascido em 1945 e falecido em $1^{\circ}$ de julho de 2019 [N. do E.].
\end{abstract}


the duty of motivation regarding sentences, showing that in pre-modern societies this duty was considered an accessory instrument, necessary only for the preservation of royal law. Then, the content analysis method was used to evaluate its specificities regarding the characteristics of the appeals (origin, matter, rationale) and of the recurrent parts (gender, social status). Correlations were identified between the applicants' characteristics, the matters contested and the types of reasoning employed, and in the end it was possible to conclude that the decisions made during this period may be characterized as transitional jurisprudence, midway between the pluralistic reasoning of the old regime and the legalistic foundation typical of modernity.

\section{KEYWORDS}

Motivation of decisions. Appeal. Supreme Court of Justice. Brazil. Portugal.

\section{A MOTIVAÇÃO DAS SENTENÇAS NA TRADIÇÃO HISTÓRICA PORTUGUESA E BRASILEIRA}

O regime da motivação das sentenças na tradição jurídica europeia é um daqueles casos exemplares quanto ao modo como mudam os sentidos das questões da dogmática jurídica (HESPANHA, 2015a). Na atualidade a motivação das sentenças está sobretudo relacionada com a limitação do arbítrio judicial, valorado negativamente em função das ideias de que o direito é criado pela lei e de que o papel dos juízes é apenas o de aplicarem a casos concretos as soluções normativas expressas nessa fonte primária do direito ${ }^{2}$. Nesses termos, a motivação das sentenças desempenha hoje um papel central na comprovação da legitimidade do direito, e não apenas uma função adjetiva relacionada aos aspectos formais (estilo) da sentença ou a uma função pedagógica de esclarecimento das partes ou do público em geral. Na tradição anterior a motivação das sentenças não era perspectivada deste modo, sendo relacionada com outros interesses e, por isso, desvalorizada, desaconselhada e até mesmo proibida ${ }^{3}$.

A obrigação de exprimir os motivos das sentenças não aparece nos primeiros textos do direito comum sobre os requisitos das sentenças. Então os requisitos apresentados são sobretudo formais, relativos à leitura das sentenças (recitatio, C.7.44.1), à língua em que deviam ser escritas (grego, latim, vernáculo, C.7.45.12) ou até à posição adotada pelo juiz ao proferi-las (de pé, sentado). Também eram relevantes o lugar e o tempo em que as sentenças eram proferidas: não o podiam ser em tempo feriado, de noite ou em lugares indignos como lupanares ou tabernas (BALDO, 1572, p. 280).

2 O pós positivismo valora ainda a motivação das sentenças no plano da averiguação da observância pelo juiz de um percurso racional ou argumentativamente adequado (ou recebido) de tirar conclusões jurídicas.

3 Sobre o tema há historiografia recente muito interessante: Aliste Santos (2011); Biscotti (2012); Gil (2013); Gorla (1979, 1980); Hocks (2002); Lorente; Garriga (1997); Oberto (2008); Ranieri (1986); Scholz (1977); Taruffo (1974); Villar (2012). 
Em comentários a esses textos, os primeiros juristas medievais insinuam requisitos adicionais, de caráter menos formal: as sentenças tinham que ser, desde logo, inteligíveis (BALDO, 1572, p. 280). Acúrsio (1592, p. 2.120) escreve também que se deve julgar a partir da "lei” (referindose aos textos de direito romano, que não eram leis, mas textos doutrinais), e não a partir de exemplos ${ }^{4}$. O que está aqui em causa é a questão de saber se de um caso particular se pode concluir para outro caso particular, em virtude da dificuldade de estabelecer um juízo de analogia. Para Acúrsio (1592, p. 2.120), o processo intelectual correto era o de orientar a decisão pela solução comum estabelecida nas fontes ou ditada pelo seu sentimento de justiça ${ }^{5}$.

Mais substancial era a referência a que a decisão devia ser deliberada. Isto era ventilado a propósito da postura corporal do juiz ao dar a sentença. Rolandino dei Romanzi (apud OBERTO, 2008) justificava a opinião de que o juiz devia sentar-se para dar a sentença, considerando que o espírito está mais sossegado nessa posição ${ }^{6}$. Pauli de Castro (1544, p. 132) confirma a necessidade de que a sentença não seja dada de supetão, mas com deliberação ${ }^{7}$, e a determinação já se encontrava expressa nas fontes justinianeias $\left(\mathrm{C} .7 .44 .2^{8}\right)$. Apenas as causas informais, de pequena monta, poderiam ser decididas segundo o arbítrio do juiz - o que, fosse como fosse, implicaria sempre ponderação, dado que o próprio arbítrio implicava alguma regra.

Em todo o caso, exigir uma ponderação prévia da decisão não implicava a publicitação dos seus fundamentos. Pelo contrário, a doutrina temia que uma explicitação demasiada das causas de decidir diminuísse a autoridade da decisão e fomentasse a sua não aceitação, com o consequente recurso - o tema era sugerido em trecho do Digesto (D.27.1.37) que se referia a uma decisão do pretor sobre escusa de tutor fundada em razão de direito que, realmente, não existia. Por essa razão diversos autores recomendam que o juiz não explicite as causas da decisão, na medida em que isso poderia minar a sua eficácia. Giacomo Oberto (2008) refere vários juristas que aconselhavam que o juiz prudente não revelasse as causas da decisão, a não ser que a isso fosse obrigado. Nesse sentido,

4 Cf. OBERTO, 2008.

5 “An iudex, secundum quod alius indicavit in consimili casu proferre debeat, sequendo talem sententiam, quaeritur. Respondeo quod non [...] sed secundum quod sibi videtur, sequendo leges, \& et iustitiam iudicare debet” [Perguntase se o juiz deve decidir segundo o que outro indicou para um caso semelhante, seguindo essa sentença. Respondo que não [...] mas que deve julgar segundo o que lhe parece, seguindo as leis e a justiça].

6 “Magis quietum animum habet, quando sedet”.

7 "Non subitas, sed deliberatione habita post negotium sententias ponderatas sibi ante forment”. "Non debent sententiae ferri subito, sed cum deliberatione”. Mesmo quando as decisões se limitassem a ratificar um compromisso, deviam deixá-lo amadurecer, sob pena de equivalerem a decisões dadas sem conhecimento da causa ("videtur etiam quod sententiae arbitrorum quae ferunt statim facto compromisso non valeant quasi latae sint causa non cognita”).

8 "Imperatores Valentinianus, Valens, Gratianu. Hac lege perpetua credimus ordinandum, ut iudices, quos cognoscendi et pronuntiandi necessitas teneret, non subitas, sed deliberatione habita post negotium sententias ponderatas sibi ante formarent et emendatas statim in libellum secuta fidelitate conferrent scriptasque ex libello partibus legerent, sed ne sit eis posthac copia corrigendi vel mutandi”. 
glosava Bártolo o citado texto do Digesto (D.27.1.37) ${ }^{9}$, sublinhando que o juiz não era obrigado a exprimir a causa de decidir, de modo a não arriscar a nulidade de uma sentença dada com fundamento errado que, se omitido, poderia mantê-la válida; embora admitisse que na falta de motivação se pudesse requerer a sua indicação, nomeadamente para que as partes pudessem avaliar a viabilidade de interposição de recurso (BÁRTOLO, 1585, p. 72) ${ }^{10}$. A opinião era compartilhada também por Baldo (1572, p. 276) ${ }^{11}$. Um jurista mais tardio chega a considerar pedante o juiz que entrasse no detalhe de revelar as suas razões de decidir (CAMBANIS, 1515, p. 123) ${ }^{12}$.

No direito canônico a decretal Sicut Nobis de Inocêncio III admitia que se incluísse, por costume local, um motivum no texto da sentença (Decretales, 2.27.16) ${ }^{13}$. Todavia, a doutrina mais comum acerca daquilo que o juiz devia registar de seu iter decisional era, segundo o popular Speculum de Guillaume Durand, o pedido do autor, a resposta do réu e as respectivas exceções, pedidos, alegações e atos processuais, tudo compendiado na fórmula: "Vistos e ouvidos as confissões e testemunhos, documentos, razões e alegações deduzidos por uma e outra parte em juízo, e examinado e considerado tudo, depois de diligente deliberação havida nossa e dos peritos, condeno ou absolvo desta forma” ${ }^{14}$. Estas referências bastariam para identificar o objeto da decisão e organizar o eventual recurso.

Esse é o modelo que triunfa no sul da Europa, apesar de existirem modelos diferentes de organização das sentenças. Enquanto o Tribunal da Rota Romana - que serviu de exemplo de organização formal das decisões e das sentenças - excluía a motivação do corpo da sentença, remetendo-a para um documento preparatório que estabelecia os pontos controvertidos e informava as partes (relatório), noutras regiões as próprias sentenças incluíam uma fundamentação, embora

9 "Item ex isto texto potest optime colligi, quod in sententia iudex non tenetur exprimere causam. Nam si exprimat falsam, sententia est nulla: sed si tulit simpliciter, tunc creditur tulisse sententiam veram incerta causa”.

10 "Si his casibus iudex causam non expresserit in sententia recurrimus ad eum, ut dicat causam, quae eum movit ad sententiam proferendam, cum nullus alius possit eam scire”.

11 "Cautius facit [Iudex] si simpliciter condemnat, vel absolvit [...] quia in sententia non est exprimenda causa de necessitate formae, vel legis mandato»" [o juiz é mais prudente se simplesmente condena ou absolve [...], pois na sentença não é obrigatório, por necessidade da forma ou por imperativo legal, exprimir a sua causa [fundamento]]”.

12 "Judex fatuus reputatur, qui in sententiam causam exprimit, in quo tamen communiter tenetur, quod non sit necessaria talis expressio".

13 "[...] in quibus copia prudentum habetur, id moris exsistat, quod omnia, quae iudicem movent, non exprimantur in stentiis proferendis”.

14 "Caeterum in sententiae prolatione iudex exprimere debet actoris petitionem, et rei responsionem, et eius exceptionem, et generaliter quicquid in causa utriusque petitum, vel allegatum, seu actum est, sub epilogo referat, ut dixi supra [...]; quo facto habeat paratam sententiam [...] vel saltem conclusionem ore proprio legat [...] et his verbis, vel similibus in prolatione utatur: FORMA. Visis, et auditis confessionibus et attestationibus, instrumentis, rationibus et allegationibus utriusque partis in iudicio deductis, eisque diligenter examinatis, et intellectis, deliberatione quoque nobiscum et cum peritis praehabita diligenti, talem condemno, vel absolvo. Vel altiter proferat, sicut viderit proferendum, ita tamen, quod canonibus, legibus, vel consuetudinibus conveniat approbatis, quae omnia sunt in sententia exprimenda” (DURAND apud OBERTO, 2008, nota 24). 
breve. Tal era o chamado “estilo judicial espanhol” (RANIERI, 1986), que também vigorava em Portugal por força das Ordenações Filipinas (3.66.7):

\begin{abstract}
7. E para as partes saberem se lhes convêm apelar ou agravar das sentenças definitivas ou ir com embargos a elas, e os Juízes da maior alçada entenderem melhor os fundamentos, porque os juízes inferiores se movem a condenar, ou absolver, mandamos que todos nossos Desembargadores, \& quaisquer outros julgadores, ora sejam Letrados, ora o não sejam, declarem especificadamente em suas sentenças definitivas, assim na primeira instância, como no caso da apelação, ou agravo, ou revista, as causas em que se fundaram a condenar ou a absolver, ou a confirmar, ou revogar. E o Julgador que puser sentença definitiva contra a forma desta Ordenação, se no caso tiver alçada, pagará vinte cruzados; e se houver dele apelação, ou agravo, pagará dez cruzados para a parte em cujo prejuízo for posta a dita sentença definitiva.
\end{abstract}

Note-se que o descumprimento do dever de fundamentação ensejava a imposição de multa, mas não causava a nulidade da sentença, como seria natural caso fosse considerada seu elemento essencial. É que esse tipo de determinações não se relacionava à justiça substancial da decisão, mas a uma política régia de limitação do poder do corpo dos juízes, paralela a outras medidas voltadas a tornar o direito mais seguro e previsível - como a redação e codificação do direito régio, a reclamação pelo rei da competência para decidir as dúvidas de interpretação do direito régio e a obrigatoriedade de se aplicar esse direito como critério primordial de julgamento, relegando-se o direito prudencial dos juristas à categoria de direito subsidiário. Julgar segundo a lei régia, redigida em vernáculo e liberta de interpretações doutrinais obscuras tornava mais transparentes os motivos da decisão e, por isso, facilitava o recurso das partes prejudicadas por uma sentença errada. Porém, não se podendo excluir os critérios não legais de decisão, exigia-se dos juízes que, pelo menos, indicassem os seus motivos, sob pena de terem de indenizar as partes pelo prejuízo causado por uma sentença com motivação obscura, ainda que eventualmente legítima.

A doutrina portuguesa se movia nestas águas. Manuel Gonçalves da Silva (1731, 3.66), no seu comentário às Ordenações, refere:

[1] Está aqui estabelecido sob certas penas que todos os juízes, tanto os inferiores como os superiores, mesmo nas relações, devam exprimir as causas das suas sentenças, que os levam a absolver ou a condenar, a revogar ou a confirmar as sentenças [cita Mendes de Castro, Practica, p. 1, lib. 3, cap. 17, in princ.]. [2] No que se vê que a nossa lei régia se afasta do direito comum, segundo o qual o juiz não é obrigado a exprimir a causa na sentença, dependendo do seu arbítrio fazê-lo ou não [cita o Digesto 27.1.37, Decretais 2.27.16 e doutrina ibérica: Agostinho e Manuel Barbosa, Altamirano e Manuel Mendes de Castro].

A mesma opinião tinha Manuel Mendes de Castro (1619, c. 17), que salientava, no entanto, que a proibição não afetava a validade de sentença que não cumprisse a determinação - marcando assim a diferença entre a falta de motivação e as causas de nulidade da sentença, também reguladas pelas Ordenações (3.75). De fato as Ordenações contemplavam, e em termos muito mais dramáticos, 
os casos em que a sentença era nula, não por lhe faltar a indicação das causas de decidir, mas por, mais radicalmente, faltar-lhe uma causa aceitável, legítima, de decidir. Os títulos 3.75 e 3.95 das Ordenações Filipinas enumeravam essas causas de nulidade ou revisão extraordinária (revista), que se relacionavam com a preterição de formalidades essenciais, como a citação; com circunstâncias que afetavam a legitimidade dos julgadores, como a falta de competência legal, a falta do número requerido de juízes, o suborno ou peita; e com a contradição decisória, como nas hipóteses de julgamento contrário a sentença anterior sobre o mesmo caso (BARBOSA, 1618, 3.75; GONÇALVES DA SILVA, 1731, 3.75).

Mais relevante do ponto de vista que aqui interessa era, porém, a nulidade decorrente da falta de motivos (causae) de fato ou de direito. A sentença carecia de causas de fato quando se baseava em provas falsas ou invocava fatos (facta) inexistentes, e carecia de causas de direito quando decidia contra direito expresso ou dava origem a injustiça notória. Num caso ou no outro o ânimo do juiz, intencionalmente ou por erro, fora desviado da reta direção, e essa falha deontológica no ofício de julgar provocava a nulidade da sentença, para além de fazer incorrer o juiz em faltas graves do foro espiritual ou temporal. Para que consequências tão severas tivessem lugar era preciso que fosse muito claro e incontroverso que o que movera o ânimo do juiz (o motivum, aquilo que move) fora errado ou falso. Por isso, o preceito das Ordenações (3.75.pr.) exigia que a sentença fosse dada "contra nossas Ordenações, ou contra direito expresso”. A doutrina entendia esta expressão como abrangendo (i) a sentença dada precipitadamente e em tempo tão breve que levasse a supor que os juízes nem tinham podido ver os autos; (ii) a sentença que contrariasse o direito claro e manifesto ou as leis, sobretudo aquelas contidas no corpo do direito e que não costumassem ser ignoradas (mas não as obscuras ou de interpretação controversa, ou as novas e não notórias); (iii) a sentença proferida contra a opinião comum unanimemente seguida; (iv) e, mais em geral, aquela em que a injustiça se tornasse notória a partir da análise do seu corpo ou do relatório (BARBOSA, 1618, 3.75; GONÇALVES DA SILVA, 1731, 3.75). Mas a falta de causa de uma sentença englobava também aquelas que estivessem erradas quanto aos seus fundamentos de fato ou fossem manifestamente injustas por falta de causa, invocando causas falsas ou peças processuais (acta) inexistentes (GONÇALVES DA SILVA, 1731, 3.75; MACEDO, 1660, p. 60; PEGAS, 1729, 1.58; PORTUGAL, 1699, с. 30).

Outras circunstâncias, embora pudessem não importar nulidade, autorizavam o recurso extraordinário de revista: basear-se a sentença em provas falsas, estar o juiz subornado ou peitado, ser dada por injustiça notória (CAMINHA, 1746, p. 126; MENDES DE CASTRO, 1619, 2.20; Ordenações, 3.75.pr e 3.87.1; PEREIRA, 1664, c. V; VALASCO, A., 1597, c. 51; VALASCO, T., 1679, c. 90). Embora esse conceito não estivesse concretizado nas Ordenações, a doutrina pendia para 
entender que seria o caso de decisão baseada numa opinião singular ou que fosse contra a razão natural (MELO FREIRE DOS REIS, 1789, 4.23.28; MENDES DE CASTRO, 1619, c. 20).

Ou seja, para a doutrina do direito comum, tal como recebida em Portugal, a inexistência de uma declaração expressa dos motivos (causas) da sentença não era um vício substancial da decisão, mas apenas um requisito externo que a tornava mais clara e orientava as partes quanto às possibilidades de reação. O que verdadeiramente feria de morte uma sentença não era a sua discrição quanto aos motivos; era a falta deles, a sua arbitrariedade, o fato de ela não resultar de deliberação ou juízo que tivesse seguido o fundamental da ordem judiciária, a cargo de julgadores competentes e honestos. Ou, havendo juízo, o fato de ele se orientar por critérios notoriamente errados e contrários à justiça. Em qualquer desses casos não se poderia falar de iudicium, não se podia falar de justiça; o alegado juiz apropriara-se da lide (facere litem suam) e julgara a seu arbítrio, a desaforo, incorrendo no mais grave dos crimes passíveis de serem cometidos por um magistrado (HESPANHA, 2015b).

Nesses termos, o mais natural era que a motivação expressa das sentenças fosse vista com cautela, pois, por muito útil que fosse para as partes, punha em risco a própria autoridade das decisões judiciais. Foi essa ponderação que levou um autor de referência, o cardeal Giovanni Battista de Luca, a recomendar que a exposição dos motivos fosse feita de forma autoritária e grave. De Luca (1697) distinguia, a este propósito, o estilo das peças judiciais em que o tribunal dava conta das suas razões de decidir (como os relatórios da Rota romana ou dos grandes tribunais de Florença, de Siena ou de Luca) do estilo dos jurisconsultos que, em textos extrajudiciais ${ }^{15}$ (como as "impropriamente chamadas” decisiones $)^{16}$, desenvolviam os motivos que poderiam justificar uma decisão real ou imaginária. Nessas últimas se justificava uma argumentação mais extensa, garrida, e adornada de citações ou mesmo apenas opinativa ou menos nítida, pois era dirigida a um público vasto, por juristas desejosos de ganhar audiência e fama. Em contrapartida, nas peças justificativas de natureza judicial ${ }^{17}$ o estilo devia ser seco: adotando um tom “magistral e grave”, como seria próprio de um tribunal provido de muitos e doutos jurisconsultos, onde seria muito inconveniente usar o estilo de um advogado jovem ${ }^{18}$. A novidade da divulgação impressa dos relatórios dos grandes tribunais, que

15 "Quando, não sendo isso requerido pelo estilo do tribunal, alguns dos juízes ou advogados, depois da causa se encerrar, organizam um discurso sobre ela para justificar as suas posições, a que chamam decisões".

16 DE LUCA, 1697, ns. 1 e 2. Deveriam antes chamar "anotações" a estes textos.

17 "Quando estes discursos se formam obrigatoriamente pelo próprio estilo do tribunal, para buscar as leis ou estilos do tribunal antes que se chegue à sentença, dando conta dos motivos ou sentidos do tribunal para julgar de uma ou outra forma, preparando a decisão futura” (DE LUCA, 1697, n. 3).

18 "Parlare da maestro e da provetto giuresconsulto, pressuponendo quelle regole, overo proposizioni, le quali siano cognite, o che non si cointrovertono dalle parti e da loro defensori. Ornando solamente con le allegazioni quei punti, e quelle proposizioni, alle quali si ristringa la difficoltà della causa [...] con autorità e con ragioni legali. Usando anche nelle autorità lo stile grave, e da maestro, coè di valersi delle autorità piu stringenti, e piu antiche e accreditate" (DE LUCA, 1697, n. 7). 
ampliava o seu auditório, teria feito correr o risco de obrigar a uma explicação mais detalhada da causa e dos motivos e, com isto, aumentara o risco de confundir os dois estilos de arrazoar, popularizando e diminuindo a autoridade da motivação dada pelos tribunais, tanto mais que as coleções extrajudiciais - meramente doutrinais - de resoluções de casos vinham abusivamente adotando o título de “decisões”.

Ou seja, mesmo nos finais do século XVII, já num período de crise da autoridade dos tribunais, ainda permanece viva a ideia de que a autoridade das decisões se justifica por razões endógenas à consciência dos juízes. Quando muito explicitáveis no círculo restrito de discussão dos grandes tribunais coletivos, mas apenas parca e prudentemente comunicáveis a um público muito restrito, sempre num estilo que sublinhasse a sua autoridade intrínseca.

Para a doutrina de então, o escrutínio do julgador reside ainda na consciência. Julgar mal é, antes de julgar contra a lei ou contra o direito, julgar contra a própria consciência, ou seja, contra aquele pedagogo da alma que nos avisa do que é bom e do que é mau. Os tratados de moral continham uma série de preceitos para diagnosticar os vários estados de consciência (certa, errada, dubitativa, escrupulosa) e para corrigi-la em conformidade. Complementarmente, também os tratados de direito continham regras para evitar julgamentos de risco: seguir as "leis”, a opinião comum, o voto da maioria e, antes de tudo, cultivar a virtude e procurar os consensos racionais (VELASCO, 1612, p. 14).

A sindicância pública do processo decisório dos juízes que mais tarde se procurará obter com a obrigatoriedade da explicitação das causas de decidir é um objetivo ainda incompreensível e inútil, nesse período. E a situação não mudará tão rapidamente: até o final do século XIX, centúria do liberalismo e da codificação, subsiste entre os juristas portugueses, e também entre os do Brasil recém-independente, a doutrina de direito comum que atribui um papel menor à fundamentação das sentenças. Ainda estribada no mesmo título das Ordenações (3.66.7), entende a doutrina oitocentesca que as sentenças devem ter como atributos essenciais elementos relacionados à preservação do direito régio (adequação às provas, à lei e à jurisprudência); da autenticidade e integridade formal da decisão (escrita, assinada, concisa, clara, inteligível, certa e determinada); e da honestidade e prudência do julgador (honesto, sem peita ou falsas provas, sem precipitação, expondo o pedido, a defesa, as provas e os nomes dos litigantes $)^{19}$. Mesmo quando referem à necessidade de apresentação das “causas em que se fundaram para emitir a sentença”, os juristas esclarecem tratar-se de elemento meramente acessório à instrução das partes quanto à conveniência de eventual apelação, ressalvando não se

19 Em Portugal o demonstram as obras de Duarte Nazareth, 1866, p. 342; Pereira e Sousa, 1820, p. 180; Pereira e Sousa, 1834, p. 264. No Brasil o demonstram as obras de Moraes de Carvalho, 1850, p. 180; Pimenta Bueno, 1858 , p. 99. 
caracterizar a nulidade quando não se apresentarem os seus fundamentos - como se verifica na obra do jurista português Pereira e Sousa (1834, p. 264), que esclarece em nota de rodapé:

Deve a sentença ser clara, certa, conforme ao libelo, às leis e aos autos, fundamentada, escrita e publicada.

Nota 568: indica a Ord. Fil. 3, 66, § 7. Deve o juiz especificar na sentença as causas e fundamentos da decisão. A Legislação Pátria emendou nesta parte o direito comum. [...] Mas faltando a expressão dos fundamentos da decisão, nem por isso a sentença é nula.

Nas “adições às primeiras linhas de Pereira e Sousa” por Manuel de Almeida e Sousa de Lobão (1855) a posição é ratificada. Considera o autor que a sentença deve ser fundamentada nos termos das Ordenações, "para os juízes mostrarem ao público a própria jurisprudência e o exato exame dos autos” (LOBÃO, 1855, p. 685) - ou seja, para demonstrar a retidão de conduta do seu julgamento pessoal, não para assegurar o controle popular da legalidade das sentenças.

O entendimento também é adotado pela doutrina brasileira. José Antônio Pimenta Bueno (1858, p. 114) indica que a sentença não fundamentada é irregular, devendo o julgador aclarar as razões do julgamento “para as partes saberem se lhes convém apelar”. O objetivo é também limitar o arbítrio dos juízes, não em virtude de um controle de legalidade de fundamento democráticorepresentativo, mas principalmente para demonstrar a justiça da sentença, contribuindo assim para aumentar a sua força moral:

Assim se conhecerá se os autos foram bem examinados, a questão bem reconhecida e a lei bem aplicada. Este preceito, que faz com que a sentença encerre sua própria justificação, ou demonstre sua própria justiça, dá-lhe grande força moral, e limita muito o arbítrio dos juízes (PIMENTA BUENO, 1858, p. 114).

Como para a doutrina portuguesa, também para Pimenta Bueno a sentença sem fundamentação não é nula; nulidade, somente para a sentença dada por falsa causa ou sem causa, “ou o julgador erre quanto ao facto, ou quanto à disposição da lei, considerando como causa, o que não devia como tal considerar” (PIMENTA BUENO, 1858, p. 99).

Percebe-se como as doutrinas portuguesa e brasileira estão alinhadas, e nem poderia ser diferente - já que durante todo o período imperial o processo civil brasileiro permaneceu regulado pelas Ordenações Filipinas. Apesar da publicação da Consolidação do Processo Civil de Antônio Joaquim Ribas em 1879, somente em 1890 o Regulamento 737/1850, criado para a regulação do procedimento adotado nas causas comerciais, passa a ser adotado também para o processo civil - o que, de resto, também não muda o panorama geral: seguindo o exemplo das Ordenações, o Regulamento considera nulas as sentenças ilegais, mas não sanciona com nulidade a ausência ou ilegalidade dos seus motivos: 
Art. 232. A sentença deve ser clara, sumariando o Juiz o pedido e a contestação com os fundamentos respectivos, motivando com precisão o seu julgado, e declarando sob sua responsabilidade a lei, uso ou estilo em que se funda.

[...]

Art. 680. A sentença é nula:

$\S 1 .^{\circ}$ Sendo dada por Juiz incompetente, suspeito, peitado ou subornado;

$\S 2 .^{\circ}$ Sendo proferida contra a expressa disposição da Legislação Comercial (art. 2. ${ }^{\circ}$ );

A ilegalidade da decisão e não dos motivos e enunciado dela constitui esta nulidade;

$\S 3 .^{\circ}$ Sendo fundada em instrumentos ou depoimentos julgados falsos em Juízo competente.

$\S 4 .^{\circ}$ Sendo o processo em que ela foi proferida anulado em razão das nulidades referidas no

Capítulo antecedente.

\section{A MOTIVAÇÃO DAS SENTENÇAS NOS STJS BRASILEIRO E PORTUGUÊS}

A escolha das decisões sobre o recurso de revista justifica-se, sobretudo por razões práticas - a disponibilidade de um corpo de decisões acessíveis. Do ponto de vista substancial também é relevante o fato de que, dada a suprema hierarquia destes tribunais, o seu padrão de motivação influenciasse os tribunais inferiores e se instituísse como modelo. Em todo o caso, a opção por este campo de observação introduz fortes distorções de análise: é que pela lógica dos supremos tribunais inspirados na Cassation, eles apenas deviam averiguar a ilegalidade da decisão recorrida e, por isso, o fundamento da decisão de concessão ou denegação da revista deveria ser, invariavelmente, a violação de uma lei, de direito substantivo ou de direito adjetivo. É certo que, como se verá a seguir, o modelo dos STJs brasileiro e português alargou a competência destes tribunais, não apenas ao conhecimento em primeira instância de ilícitos de certos funcionários superiores ou de conflitos de jurisdição, mas também aos casos de "injustiça notória”.

Importa, por isso, que se detalhe um pouco qual era o fundamento do recurso de revista e de que modo ele pode enviesar os resultados da análise.

Nas primeiras décadas de existência do STJ português, a necessidade da revista surgia da preocupação com a garantia da divisão de poderes. Melhor, com a defesa da legalidade estabelecida pelos órgãos representativos (SÁ, 1872). Era o modelo da Cassation $^{20}$, que sujeitava a estrita vigilância os atos de execução judicial ou administrativa da lei. No caso dos atos administrativos o controle da legalidade pertenceria ao Conselho de Estado, já que não se podia admitir que um órgão judicial vigiasse a atividade executiva. No caso dos atos judiciais esse controle era confiado a um órgão judiciário supremo, que se limitava a anular (quebrar, do francês casser) a sentença ilegal, desde que a ilegalidade afetasse um elemento essencial da decisão, ensejando a sua nulidade. Embora

20 Adotado pela Constituição Francesa de 1791 (arts. 19-20), pela Constituição de Cádis de 1812 (arts. 259-261) e pela Constituição Portuguesa de 1822 (arts. 191-193). Nesses termos estritos estão desenhados os fundamentos e efeitos do recurso de revista no primeiro regimento do STJ, de 19 de maio de 1832 (FERRAZ, 1841). 
o tribunal supremo pertencesse ao Poder Judiciário, a sua decisão sobre a revista era algo de extraordinário, fora da ordem dos recursos ${ }^{21}$. Daí que o STJ fosse considerado como um tribunal misto - entre político e jurídico - e que a natureza e os efeitos das suas revistas não fossem as de recursos ordinários “de terceira instância”. Limitava-se, portanto, ao indispensável para evitar a desobediência à lei: anular a sentença recorrida, sem decidir sobre o fundo da causa, remetendo-a de novo para uma relação.

A necessidade de uniformização da jurisprudência também era vista, sobretudo, como uma questão de conveniência política, pois afetava a igualdade dos cidadãos perante a lei. Nesse sentido, tinha um significado político semelhante ao do fim dos privilégios e dos foros privilegiados. Mas não era uma preocupação primária, pois se entendia, de acordo com uma teoria algo ingênua da interpretação, que se as leis fossem respeitadas as decisões não divergiriam. E se isso acontecesse a solução teria que vir do legislativo, por meio de uma interpretação autêntica (référé législatif) ou pelo aperfeiçoamento da legislação ambígua.

Paralelamente à preocupação teórica decorrente da separação dos poderes existia também, nesta primeira fase da organização judiciária liberal, uma forte preocupação prática: a de evitar o arbítrio judicial. Isso porque se entendia (e as discussões parlamentares são muito eloquentes nesse aspecto) que as principais origens dos atentados à liberdade, igualdade e direitos dos cidadãos eram a corrupção e os abusos dos juízes. Essa preocupação vinha do legalismo iluminista anterior à revolução liberal, que então já ditava os regimes restritivos sobre a criação de direito doutrinal e judicial - como ilustram a Lei da Boa Razão (18 de agosto de 1769) e as limitações impostas pela Lei de 3 de novembro de 1768 ao recurso de revista, que restringiam a sua admissibilidade aos casos de ilegalidade taxativamente previstos nas Ordenações $(3.75$; 3.95$)$ e mandavam referir ao rei a interpretação das leis obscuras (1.5.5) (PEREIRA E SOUSA, 1820, p. 354).

O primeiro título das Ordenações declara absolutamente nula a sentença dada sem citação, contrária à outra já dada no mesmo caso, obtida por corrupção, fundada em falsa prova, com falta de juízes, dada por juiz incompetente ou dada contra direito expresso. Ou seja, uma sentença em que tivessem sido infringidas formalidades processuais essenciais. Mas também eram nulas sentenças dadas contra o direito material ou substantivo: o item 2 do mesmo título dedica-se à contradição com o "direito expresso", distinguindo-a da contradição contra "direito da parte” para se referir, pela expressão mais restrita, a um ponto de fato ou de direito invocado por uma das partes e controvertido pela outra. Ou seja, um direito que proviesse da interpretação e não fosse incontroverso como aquele

21 Na versão de antigo regime, esta decisão era considerada como um ato de graça (em matéria de justiça) do soberano, sendo da competência de um tribunal de graça, o Desembargo do Paço. 
que está expressamente determinado na lei. O título 3.95 acrescentava aos casos de nulidade previstos no anterior os casos de revisão ordenada pelo rei por graça especial, cujas regras de impetração, prazos e processamento são estabelecidas nos itens 1 e 3 .

As Ordenações eram, portanto, muito restritivas quanto à possibilidade de revista, estabelecendo um valor mínimo para a causa recorrida, prazos de recurso, e fixando com rigor as situações em que os erros da decisão a justificariam: falam de erros processuais específicos (falta de citação, incompetência, falsidade, peita e suborno do juiz) e, nos casos de "graça especial”, em “sentença não justamente dada” ou "não bem dada [...] notoriamente”. Nos casos de natureza mais genérica, porém, em que havia o risco de concessões abusivas, a revista só era dada depois de a sentença recorrida ser tida como injusta por dois desembargadores da relação que não tivessem votado na sentença recorrida, e que estivessem de acordo quanto ao fundamento da revista ${ }^{22}$.

Como se vê, o regime das Ordenações era grandemente recuperável por um modelo legalista do recurso de revista. Haveria alguns problemas com o conceito de direito expresso, pois não se restringia claramente o direito à lei - o que permitiria incluir casos de violação de direito doutrinal incontroverso, de natureza substantiva ou adjetiva. Tratava-se de impedir que, a propósito de erros graves de julgamento, se alongassem os feitos, tornando “ordinário” o recurso extraordinário à graça régia. O grande empecilho para um direito legalista eram as revistas por graça especial (que a doutrina ainda estendeu, com os casos de graça especialíssima $)^{23}$.

A Lei de 1768 procurava - como se disse - restringir as atribuições de revista do Desembargo do Paço, no âmbito do movimento geral de restringir o direito doutrinal e judicial e de promover a autoridade da lei, ao qual será dada uma amplitude geral logo no ano seguinte, com a Lei da Boa Razão. O preâmbulo do decreto é enfático nesse sentido ${ }^{24}$ : buscava-se o retorno ao regime estrito das Ordenações, nomeadamente quanto à interpretação de uma cláusula tão genérica como "sentença injustamente dada”. Segundo a nova lei, a revista só podia ser dada, nas causas cíveis, em caso de “injustiça notória” e de "nulidade manifesta” especificadas nas Ordenações (3.95; 3.75), interpretando-se de forma restritiva a cláusula “contra direito expresso” (3.75.pr.) como fundamento de nulidade da sentença. Igualmente acautelava interpretações especiosas da lei, relembrando o disposto nas Ordenações quanto à proibição de interpretação judicial de leis ambíguas, que deveriam

22 Cf. Ordenações Filipinas, 3.95 e no 32 a 38 do Regimento do Desembargo do Paço. Cf. ainda, sobre legislação extravagante, Manuel Fernandes Tomás (1815-1819).

23 Basicamente, o não cumprimento dos prazos para pedir a revista de graça (Ordenações, 3.95.3) ou o recurso de decisões de tribunais que não as Relações (Lei de 1779).

24 Erros graves eram também os que provocavam a nulidade da sentença (Ordenações, 3.75). Mas da sentença nula não se apelava nem se pedia revista. Agravava-se ou embargava-se. 
ser aclaradas pela Mesa Grande da Casa da Suplicação $(1.5 .5)^{25}$. E, ainda receosa de que o conceito “lei expressa” fosse demasiado largo, precisa:

E porque sobre os termos em que as sentenças se devem julgar notoriamente injustas pelo princípio de serem proferidas contra direito expresso, há também diversas opiniões que têm constituído perplexidade no direito das partes, e contrariedade nas decisões das revistas: determino que o direito expresso de que se trata nas referidas leis deve ser o direito pátrio, e não as leis imperiais ou direito civil, de que resultaria a mesma perplexidade (Lei de 3 de novembro de $1768, \S 3^{\circ}$ ).

Com isto, reduz-se o direito à lei ou, pelo menos, às interpretações unívocas do direito legislado.

Mais tarde o Decreto de 5 de novembro de 1779 também insiste neste caminho restritivo: reserva a revista, nos mesmos termos limitados, somente às decisões das relações, excluindo da possibilidade de emprego do recurso as decisões proferidas por outros tribunais superiores. Essa regra apenas podia ser removida por uma revista de graça especialíssima.

Embora não haja estudos empíricos sobre a prática de conhecimento e concessão de revistas pelo Desembargo do Paço $^{26}$, o sentido geral da legislação é o de restringir a criação de direito judicial, nomeadamente quanto à possibilidade de declaração, nos casos concretos, do que era "direito expresso” e “justiça notória”. Em princípio, a lei teria fechado a interpretação dos dois conceitos. Em todo o caso, a hipótese de um direito judicial não estava totalmente arredada. Apesar de a decisão em revista somente se aplicar ao caso recorrido, ela sempre constituía um precedente, provindo de um tribunal eminente e ratificado por graça régia, e que poderia tornar-se elemento decisivo na constituição de uma prática de julgar. Por outro lado, autorizar os juízes a examinar sem restrições inultrapassáveis a justiça ou juridicidade de uma decisão podia até funcionar contra a legalidade, sempre que eles entendessem que uma decisão conforme à lei podia ser injusta ou contra direito.

Talvez por isso o regimento do STJ português de 19 de maio de 1832 seja tão específico ao regular os casos em que se admite a revista, limitando-a às hipóteses de vícios que provocassem a nulidade das sentenças por "contravenção direta às Leis do Reino em vigor, ou seja, primeiro: preterindo-se alguma das formalidades que elas estabelecerem, sob pena de nulidade; ou, segundo: não se conformando na aplicação das mesmas com a sua literal disposição”. Como se vê, não se fala mais de decisão injusta ou contra direito, mas de violação direta das leis, entendidas na sua literal disposição. Nestes termos o arbítrio judicial na concessão da revista é muito menor - no limite, para

\footnotetext{
25 Para além disso, a lei reafirma o princípio de que não se pode insistir na revista de uma sentença em que ela já foi recusada (Ordenações, 3.95.9) e restringe os casos de revista por graça especialíssima aos casos em que a revista fosse proibida por direito ou fosse pedida fora de prazo (Lei de 3 de novembro de 1768, § 4).

26 Não serão impossíveis para o período posterior a 1755, já que a documentação do Tribunal se conserva.
} 
o otimismo legalista da época, inexistente. E, consequentemente, o poder dos juízes de “dizerem o direito” é duplamente restringido: por um lado, a liberdade dos conselheiros do STJ de definir quais são os casos de revista quase desaparece; por outro, o supremo tribunal se converte num dispositivo de controle da estrita legalidade das decisões judiciais. Ou seja, o regimento de 1832 revela ainda o vigor dos tópicos legalistas e críticos da alta magistratura letrada que tinham sido frequentes nas cortes vintistas e que continuavam vivos nos inícios da década de 1830.

No ano seguinte, o Código Comercial de 1833 corrigia um pouco este legalismo extremo, ao recuperar o fundamento da "injustiça notória” das Ordenações e dispor que, para a revista comercial, ela seria concedida nos casos de “injustiça notória”, mas só se consistisse na manifesta violação das formas substanciais do processo e nulidade de sentença por ser dada contra a determinação de lei expressa (arts. 1115-1116).

Aparentemente, a partir dos finais da década de 1830, o discurso sobre a natureza do STJ e sobre as suas competências muda, não tanto por alterações legislativas, mas por inflexão doutrinal. O que passa a constituir a principal preocupação é a uniformidade da jurisprudência e o modo como o STJ a podia promover. A discussão perde o tom eminentemente político da primeira fase, voltada para os equilíbrios constitucionais dos poderes, e desloca-se para um plano técnico da consistência do direito e da previsibilidade e segurança dos direitos das partes. Paralelamente, a atitude em relação aos juristas e juízes letrados também muda: por um lado, passa-se a acreditar que a forma mais autêntica e orgânica de realizar a uniformidade do direito é a organização dogmática dos jurisconsultos e jurisprudentes (SÁ, 1872); por outro, insiste-se num entendimento mais vasto de “direito expresso”, que abranja também os princípios gerais construídos pela doutrina; finalmente, considera-se uma violência insuportável que o STJ determine autoritariamente o sentido do direito, privando as relações da liberdade de julgar segundo o seu livre entendimento.

A partir de agora a tendência é de alargar a competência judicial do STJ no que respeita à decisão da substância da causa. Estranha-se, em primeiro lugar, que um tribunal supremo possa ser desautorizado por uma relação, a quem não pode impor uma interpretação do direito, mas apenas impedir a adoção de uma tida como contra direito. Critica-se, em seguida, a distinção "metafísica” entre a nulidade e os outros vícios da decisão recorrida. Propõe-se, então, uma escalada em vários degraus, no sentido de constituir o STJ numa verdadeira terceira instância, julgando plenamente o recurso. Este percurso não se fez de uma assentada.

Em Portugal, a Lei de 19 de dezembro de 1843 institui uma segunda revista, quando a relação tivesse insistido na orientação reprovada na primeira revista. E nesse caso a decisão do STJ seria 
vinculativa para a relação. O Código de Processo Civil de 8 de novembro de 1876 não alterou significativamente esse regime ${ }^{27}$.

A tendência para flexibilizar os fundamentos da revista, abrindo-a a uma revisão mais alargada da justiça da decisão, também estava no novo espírito do tempo. Não se tratava tanto da nostalgia do sistema de antigo regime, mas de uma recuperação do prestígio do saber jurídico e da consequente atenuação das desconfianças quanto ao efeito deletério dos juristas sobre uma ordem jurídica democrática, focada na lei. Apesar disso, o Regimento de 19 de dezembro de 1843 mantém uma formulação dos fundamentos da revista ainda bastante focada na lei (art. $1^{\circ}$ ): a nulidade do processo ou da sentença recorridos, descritas como provenientes de contrariedade com a lei ou de sua interpretação “manifestamente errada”.

O certo é que, embora a formulação da lei continuasse bastante presa ao objetivo de limitar o fundamento da revista à violação literal da lei, a doutrina entendeu que havia ocorrido uma ampliação dos fundamentos da revista. De fato, o próprio Lopes Praça (1878, p. 346) registra que “muitos escritores, com efeito, entendem que, principalmente depois que se publicou a Lei de 10 de dezembro de 1843, o Supremo Tribunal de Justiça é realmente a terceira instância judicial”. Por sua vez, José Alberto dos Reis (1909, p. 183) entende que é esta lei que marca o início de uma segunda fase da história do recurso de revista em Portugal, abrindo caminho a que o STJ se tornasse o "órgão uniformizador da jurisprudência nacional”, examinando “também se a decisão judiciária fora proferida contra o espírito da lei, embora estivesse em conformidade com a sua letra”. A Lei de 1843 teria, de fato, moldado o Código de Processo Civil de 1876 (art. 1.159). Fora este, afinal, que rompera com a orientação estritamente legalista do Regimento de 1832, empregando a expressão “julgar contra direito" para significar que, em harmonia com o artigo 16 do Código Civil,

É nula a sentença que não julgue segundo o texto e espírito da lei, e na sua falta, segundo os casos análogos prevenidos em outras leis e, ainda na falta destes, segundo os princípios do direito natural adaptados às circunstâncias do caso. E quando a lei mande recorrer aos usos ou costumes das terras para a solução das questões, a decisão que for de encontro a esses usos deve ser anulada por haver julgado contra direito (COSTA, 1898, p. 320).

No fundo, o que mudara não fora tanto a letra da lei que regulava o fundamento da revista, mas o espírito com que essa lei era lida por uma nova geração de juristas, menos dispostos a submeter as suas opiniões aos sentidos queridos pelo legislador.

Em 9 de julho de 1887 foi apresentado à Câmara dos Deputados um projeto de lei (BEIRÃO, 1887) que continha modificações significativas no sentido da completa judicialização do recurso de

27 Segundo o art. 1.162 do Código, no julgamento com relação da causa revista deve haver pelo menos cinco votos contra a decisão da revista. Cf. José Alberto dos Reis (1909, p. 183). 
revista ${ }^{28}$. Nesse projeto a revista se aproximava de um recurso ordinário, restrito à questão de direito, embora limitado à aplicação da lei e ao exato cumprimento das fórmulas e termos do processo ${ }^{29}$. Porém, há vozes que se levantam no sentido de equiparar a revista a uma terceira instância. Alexandre de Seabra, nos motivos do seu projeto de Código de Processo Civil (1869), escrevia:

É melhor dar francamente ao Supremo Tribunal o direito de cassação absoluta, ou por erro de apreciação de fato ou direito, do que estar a criar-lhe peias, de que se liberta facilmente pela porta fácil das nulidades. Por que não há de o Supremo Tribunal conhecer as relações do fato e do direito? Que diferença há entre umas e outras? Metafísicas e abstrusas distinções são essas.

O Supremo poderia conhecer como uma instância ordinária; mas não vincularia a relação, apenas forçando, porventura, a um número mais elevado de votos a favor da decisão que se afastasse da do tribunal superior. Nestes termos, apontava-se para uma solução de “diálogo” entre instâncias, como a forma “orgânica”, "natural”, de obter a uniformidade da jurisprudência. Do ponto de vista da distribuição social do poder de dizer o direito, esta solução apontava para uma recuperação decisiva do poder dos juristas como achadores do direito. Ainda em 1878, José Joaquim Lopes Praça (1878, p. 343) reafirmava este legalismo ligado a um conceito "político” da revista das sentenças pelo STJ:

\begin{abstract}
Por esta forma o Supremo Tribunal de Justiça não é uma terceira instância. Sem se envolver nos pleitos das partes diretamente, ou nos seus interesses, dirige-se principalmente a sustentar firme e inabalável o respeito da lei e a cooperar ativa e eficazmente para a uniformidade da sua aplicação. Aproxima-se dos poderes executivo e legislativo sem com eles se confundir, sem os perturbar, antes tornando possível a sua harmonia, divisão e independência. O Supremo Tribunal de Justiça não é competente para dar à lei uma interpretação geral obrigatória (C. C., art. 15, § 6); mas não deixará substituir as leis existentes pelos erros e paixões individuais, mantendo as leis em seu plenário vigor contra as deficiências judiciais e contra os possíveis excessos regulamentares do poder executivo. De certo não pode declarar nulos os regulamentos do poder executivo contrários às leis, mas é do seu dever fazer aplicar as leis livres de sofismas [...] era preciso, para completar a organização judiciária, assegurar o respeito inviolável das leis, sua sã e uniforme interpretação, dar uma alta e eficaz sanção a esta máxima fundamental de nosso direito político — a igualdade dos cidadãos perante a lei; impedir os tribunais numerosos e disseminados num território extenso, sob a pressão dos costumes locais, de antigas tradições, de aspirações diversas, impedi-los, repetimos, de fazer do país, sob o aspecto judiciário, frações federativas.
\end{abstract}

O legalismo do primeiro regimento do STJ português contrasta com o tradicionalismo do regimento do Tribunal brasileiro (Lei de 18 de setembro de 1828), em que se mantêm os fundamentos da revista do direito de antigo regime, com a sua abertura a uma apreciação genérica da “manifesta

28 Além de pretender retirar ao STJ a competência sobre a carreira e a disciplina dos juízes, criando um Supremo Conseho de Magistratura Judicial no âmbito do Ministério da Justiça.

29 Nisto se distinguindo da apelação, que versava sobre qualquer questão, de direito ou de fato. Cf. Eduardo Dally Alves de Sá (1872, p. 82): incide sobre "termos e formalidades do processo, e no mais de direito, apontando-se a lei, ou o erro do seu entendimento e aplicação”, deixando-se às relações “o direito de julgar de novo”. 
ilegalidade” e da “injustiça notória” da decisão recorrida ${ }^{30}$. É certo que os comentadores salientam a função pública da revista, como forma de garantir o respeito pela lei ${ }^{31}$. Mas a interpretação que se faz do conteúdo das expressões da "manifesta ilegalidade” e da "injustiça notória” denota que se alargava muito o conceito de "lei” e, com isso, o âmbito de concessão da revista, ao sabor da interpretação judicial ou doutrinal. Realmente, embora as decisões proferidas sempre se ativessem aos requisitos legais, pelo critério da “injustiça notória” chegavam, na prática, a examinar até mesmo detalhes fáticos dos casos concretos, reexaminando e revalorando provas e documentos - como ilustra o acórdão proferido em 18 de setembro de 1848 na revista interposta por Nicoláo Gadatt em face de Bernardo Lasser, contra decisão proferida pela Relação do Rio de Janeiro:

[...] Mas também por injustiça notória resultante do julgado no mesmo acórdão contra a prova dos autos; porquanto à vista do expendido nos artigos da contrariedade do recorrido, que contêm sua confissão, comprovada por sua própria carta de fl. 14, é evidente ter a Relação no mencionado acórdão tomado para reforma em parte da sentença fl. 155 apelada um fundamento, qual a empreitada, que longe de estar provada, antes o contrário é que está (MAFRA, 1867, p. 57).

A doutrina confirmava esse entendimento: Pimenta Bueno (1857, p. 370), por exemplo, opina que os fundamentos da revista só podem ser algum vício que importe a nulidade da sentença, seja por nulidade do processo (a “nulidade manifesta”) ou por nulidade do julgado (a “injustiça notória”). E apresenta uma tipificação desses vícios: (i) violação do direito expresso ou do texto formal da lei; (ii) violação da lei por aplicação ou interpretação manifestamente errada; (iii) violação do preceito formal da lei por omissão ou outra contravenção positiva; (iv) violação dos princípios ou preceitos fundamentais do direito, ou aplicação manifestamente errada.

Com esta abertura do conceito de "lei escrita" ou "lei positiva” abria-se, então, um enorme espaço para a anulação judicial de sentenças por via da revista e, com isto, não apenas se desistia do controle da estrita legalidade, como se creditavam os juízes para impor interpretações da lei e princípios doutrinais que pudessem promover a desaplicação da lei. Pimenta Bueno (1857, p. 371) considera que isto seria inevitável, em países que, como o Brasil, carecessem de códigos atualizados:

30 “Art. $5^{\circ}$. Ao Tribunal compete: $1^{\circ}$. Conceder ou denegar revistas nas causas, e pela maneira, que esta lei determina [...] Art. $6^{\circ}$ As revistas somente serão concedidas nas causas cíveis, e crimes, quando se verificar um dos dois casos: manifesta nulidade, ou injustiça notória nas sentenças proferidas em todos os Juízos em última instância.”

31 Segundo Pimenta Bueno (1857, p. 358): “A revista no só interesse da lei é o recurso que o ministério público, o procurador da coroa, interpõe por ocasião de violação daquela, não como parte na causa, senão como autoridade, como guarda e fiscal da ordem legal, do respeito devido à autoridade da lei. [...] O fim deste recurso não é de alterar a sorte das partes, de melhorá-la ou piorá-la; ele não aproveita nem prejudica o seu interesse particular, que continua a subsistir tal qual foi julgado. O seu único, mas importante fim é ele reivindicar o império e dignidade da lei ofendida, não consentir que passe como lícito ou vigente um princípio ilegal, um arresto oposto à tese, ao preceito dela, de reprimir enfim o abuso do julgador”. 
Os países que têm, como a França, a fortuna de possuir códigos completos e incessantemente melhorados e esclarecidos, podem e porventura devem atender essa opinião [de que os princípios não são leis positivas]. Nós, porém, que regemo-nos ainda pelas Ordenações de 1500, tão omissas para a sociedade atual que nos regulamos mais pelos princípios de direito do que por textos legais que não temos; se denegássemos este meio de cassação, daríamos grande arbítrio aos tribunais da primeira e segunda instância e enervaríamos a ação do Supremo Tribunal de Justiça.

Porém, o preço a se pagar por esse instrumento de alegada disciplina dos tribunais inferiores era a atribuição de um grande arbítrio na concessão de revistas pelo tribunal supremo, promovendo a variabilidade da jurisprudência.

É certo que a decisão do STJ em revista não obrigava o tribunal que iria julgar de novo o fundo da causa. Essa liberdade de julgamento do tribunal de primeiro grau era considerada indispensável à função de julgar, acreditando-se que era desse diálogo entre as instâncias de cassação e de revisão que resultaria uma melhoria das leis. Para Pimenta Bueno (1857), que escreve nos meados do século, a melhoria da legislação já não dependia tanto da vontade do legislador democraticamente legitimado, mas, antes, do diálogo doutrinal do corpo dos juristas ${ }^{32}$.

A tecnificação da revista, que subalterniza os seus sentidos políticos e a torna, progressivamente, um assunto de juristas, não apenas atenua o seu caráter extraordinário e a aproxima de um recurso judicial ordinário, como tende a fazê-la dependente do valor da causa: a revista era originalmente um recurso de caráter público, em que os interesses das partes eram secundários e o valor da causa era irrelevante perante a gravidade política do caso; com a sua “ordinarização” passase a ponderar o seu custo institucional pela sobrecarga que provoca aos supremos tribunais. Por isso, a tendência é a de voltar a exigir um valor da causa que supere a alçada da relação (como nas Ordenações) ou um outro valor apreciável. É o que acontece em Portugal com a Novíssima Reforma Judiciária de 21 de maio de 1841 (art. 682), e no Brasil com a Lei de 15 de março de 1842 (Reforma do Código de Processo Criminal), que fazem com que a revista deixe de ser um recurso universal para obstar a ilegalidade das sentenças.

32 Cf. Pimenta Bueno (1857, p. 376): “Demais, é de uma discussão assim ilustrada que resultam os melhoramentos que devem ser propostos com inteira segurança ao poder legislativo”. 


\section{OS RESULTADOS}

O objetivo da investigação realizada foi estudar as decisões de revista dos STJs brasileiro e português, segundo uma grelha de análise focada em vários aspectos, um dos quais foi o modelo de motivação das sentenças ${ }^{33}$.

O corpo textual foram as decisões publicadas em duas coleções, uma brasileira e outra portuguesa, facilmente acessíveis ${ }^{34}$. Ambas as coletâneas apenas publicam decisões que decidem favoravelmente ao pedido de revista. No plano da motivação das sentenças, isso não parece comprometer muito a validade da amostra, pois é de admitir que o padrão da motivação não seja muito diferente (SLEMIAN, 2017). A consistência da coletânea portuguesa é maior que a da brasileira, que reúne somente uma parte das decisões efetivamente tomadas, enquanto a portuguesa aparentemente reúne todas as decisões. A grelha de questionamento e o modelo de recolha e registro dos dados basearam-se nas ferramentas elaboradas por Hespanha em 2010, para um projeto de investigação no âmbito da FCT ${ }^{35}$. No estado atual das amostras, a distribuição das decisões por anos é a seguinte ${ }^{36}$ :

33 O trabalho de investigação foi desenvolvido com os alunos de mestrado do Programa de Pós-Graduação em Direito do Centro Universitário Internacional (Uninter) entre 2017 e 2018. A pesquisa foi iniciada em outubro de 2017, sob orientação e coordenação de António Manuel Hespanha. A partir de novembro do mesmo ano Walter Guandalini Junior passou a colaborar nos trabalhos, realizando o acompanhamento local dos estudantes pesquisadores: Antônio Marcos Quinupa, Eduardo Mazarotto, Livia Solana Pfuetzenreiter de Lima Teixeira, Luana Rosa, Sandra Bazzo Barwinski, Thaís Brodbeck, Tiemi Saito e Vanessa Fransozi. Os estudantes se responsabilizaram pela coleta inicial dos dados brasileiros, posteriormente revisados em sua integralidade, tabulados e estruturados por Walter Guandalini Junior. António Manuel Hespanha se ocupou da coleta dos dados portugueses. O conjunto dos dados foi posteriormente submetido ao tratamento e análise de António Manuel Hespanha e Walter Guandalini Junior, que também realizaram a revisão teórica que fornece o contexto da investigação empírica.

34 Para Portugal a coletânea dirigida por Barros Corte Real e Cardoso Castello Branco (1859-1884): Collecção dos accordaos que contêem materia legislativa proferidos pelo Supremo Tribunal de Justiça desde a epocha da sua instalação. Para o Brasil a coletênea organizada por Mafra (1867): Jurisprudência dos Tribunais.

35 “Análise textual da estrutura, legibilidade e fundamentação doutrinal e normativa de textos judiciais portugueses. Um contributo para o aperfeiçoamento da justiça”, PTDC/CPJ-JUR/111210/2009 (lacrado a 7 de dezembro de 2009; avaliado, aprovado e financiado; mas não iniciado por motivos pessoais). Essas ferramentas foram depois adotadas no projeto apresentado por António Manuel Hespanha à Uninter em 2015. Entretanto, o colega Sidnei Machado, da Faculdade de Direito da UFPR, adaptou o questionário e transferiu-o para a plataforma Google forms ${ }^{\circledR}$, tendo vindo a usá-lo para análise de decisões no âmbito do direito do trabalho. Também a colega Andreia Slemian (Universidade Federal de São Paulo, Departamento de História) se inspirou nele para organizar os estudos que tem vindo a fazer sobre a motivação das sentenças do STJ brasileiro. A ambos o agradecimento pelos testes e respectivo feedback.

36 A amostra das decisões portuguesas precisaria ser completada para a perfeita comparação com os dados brasileiros. O falecimento de António Manuel Hespanha em $1^{\circ}$ de julho de 2019 impediu a conclusão desse trabalho, mas a amostra existente já é suficiente para uma comparação preliminar. 

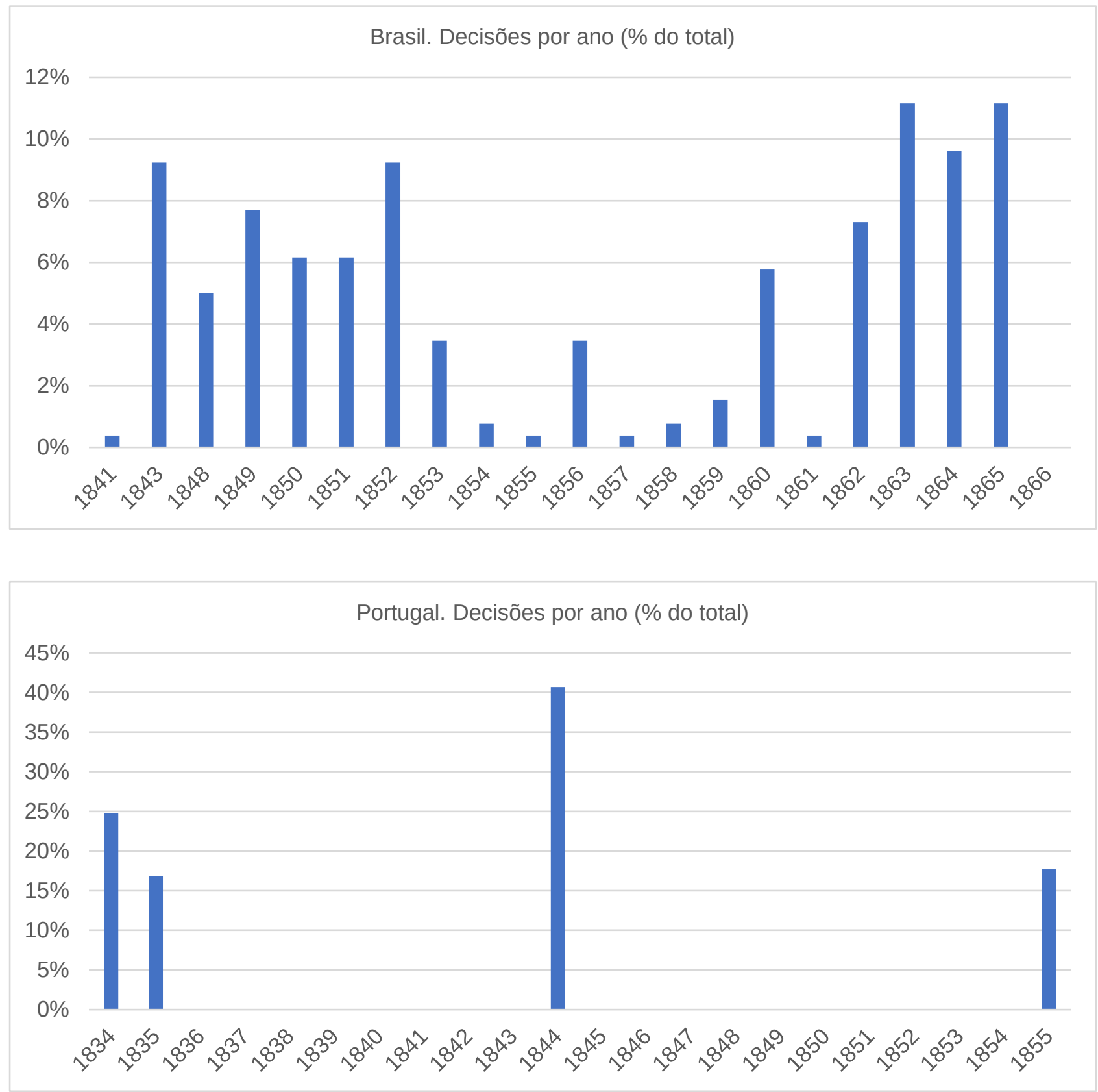

A folha de recolha de dados estava organizada nos seguintes aspectos:

- $\quad$ identificação do analista e da decisão analisada;

- identificação das partes (nome, gênero, estatuto social, posição na ação inicial);

- $\quad$ identificação da causa (tribunal recorrido, data do recurso, resumo da ação inicial e dos recursos, ramo de direito e assunto específico da ação inicial);

- $\quad$ identificação da sentença (data, extensão, resultado, fundamentação, fontes de direito invocadas [por épocas], autores citados [por épocas]); 
- $\quad$ identificação dos juízes decisores (nomes dos que assinaram e dos que votaram vencidos).

Para rentabilizar o trabalho e prever futuras utilizações historiográficas, o elenco dos temas analisados foi alargado a questões que não tinham diretamente a ver com a fundamentação das sentenças. Iniciado o trabalho, logo se viu que alguns dos campos não forneciam dados sistemáticos ou fiáveis para tratamento quantitativo. Cedo se chegou às conclusões, por exemplo:

- $\quad$ de que raramente havia dados sobre o estatuto social das partes, o que dificultava qualquer estudo sociológico do recurso à justiça de ultimíssima instância. Detalhes da decisão permitiam deduzir indiretamente tais informações, mas em quantidade insuficiente para afirmações conclusivas;

- $\quad$ de que nunca havia a indicação da data de propositura da ação inicial ou do recurso, o que impedia estudar os ritmos dos processos;

- $\quad$ de que muito raramente se citavam autores em apoio das decisões (no caso do tribunal brasileiro, nunca).

Em contrapartida, pareceu possível analisar a frequência dos temas dos litígios iniciais, já que os temas do recurso são, naturalmente, quase sempre, os temas de direito processual que possibilitavam o recurso. Acontece, porém, que nem sempre a partir da decisão final se consegue reconstituir o tema do litígio inicial ${ }^{37}$. Identificado o tema desse litígio, é possível identificar o ramo de direito em causa, ou mesmo, mais concretamente, o instituto a que dizia respeito. Para este efeito foram elaboradas tabelas de classificação que permitissem fazer estatísticas de distribuição temática dos litígios. Mas a análise sobre as temáticas em que recaía essa litigiosidade não pode valer senão para o universo de questões que chegaram aos STJs e receberam acolhimento. Qualquer extrapolação para universos mais vastos seria arriscada.

A compilação mais completa dos dados para o STJ brasileiro permitiu uma análise mais detalhada, em comparação com as informações obtidas para o STJ português. No Brasil se observa, em primeiro lugar, uma predominância de recursos originários da Relação da Bahia, o que se compreende pela importância econômica e demográfica da província no período estudado. Essa predominância geográfica se repete nos tribunais especializados de Direito Comercial.

37 No caso do STJ português, não foi possível determinar o assunto da questão inicial em 37\% dos casos e nem sequer o ramo de direito em 19\% dos casos; no do STJ brasileiro, esses valores baixam a $15 \%$ e $2 \%$. 


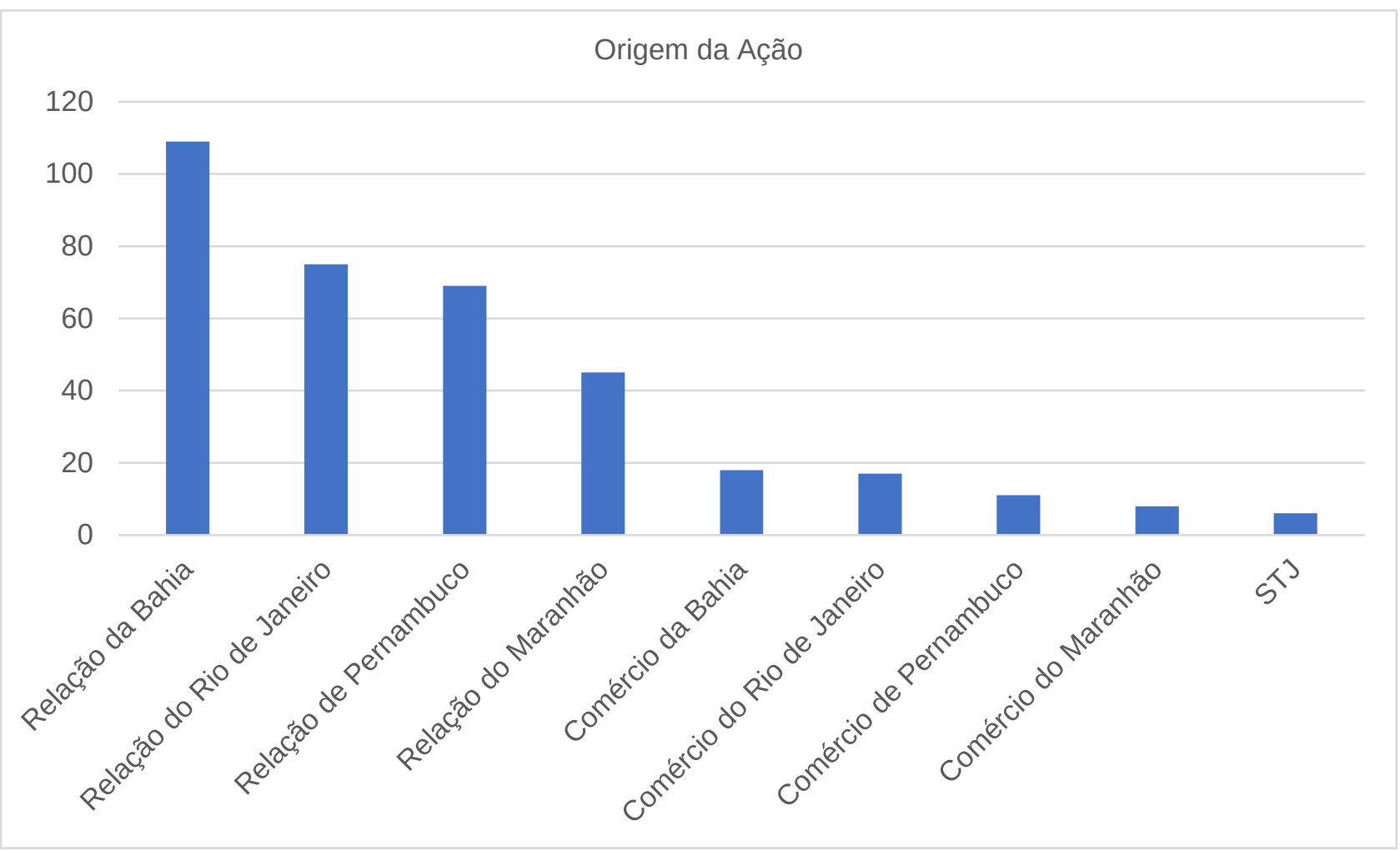

Quanto ao gênero dos recorrentes, é predominantemente masculino (69,83\%). Mesmo quando as mulheres decidem apresentar recurso, é mais comum que o façam em conjunto com homens $(9,21 \%)$ do que isoladamente $(4,46 \%)$, sendo a proporção de recursos apresentados individualmente por mulheres inferior à de recursos interpostos por pessoas jurídicas (8,10\%) e pelo Estado (6,14\%) (e superior apenas à de mulheres com representação masculina - 2,23\%). Observase o recorte de gênero também quanto à matéria dos recursos interpostos: entre homens, o assunto mais discutido são contratos civis e comerciais, a indicar a relevância de sua atividade na esfera pública negocial; entre mulheres se observa uma predominância de recursos tratando de direitos reais e sucessões, indicando a sua atividade voltada à organização e preservação da vida doméstica. Quando os recursos são interpostos em conjunto por homens e mulheres o tema predominante são as sucessões, demonstrando a interferência masculina na gestão do patrimônio familiar, mesmo quando se trata de direitos subjetivos das mulheres. As pessoas jurídicas tratam principalmente de assuntos de direito comercial, e o Estado recorre principalmente sobre temas fiscais. 


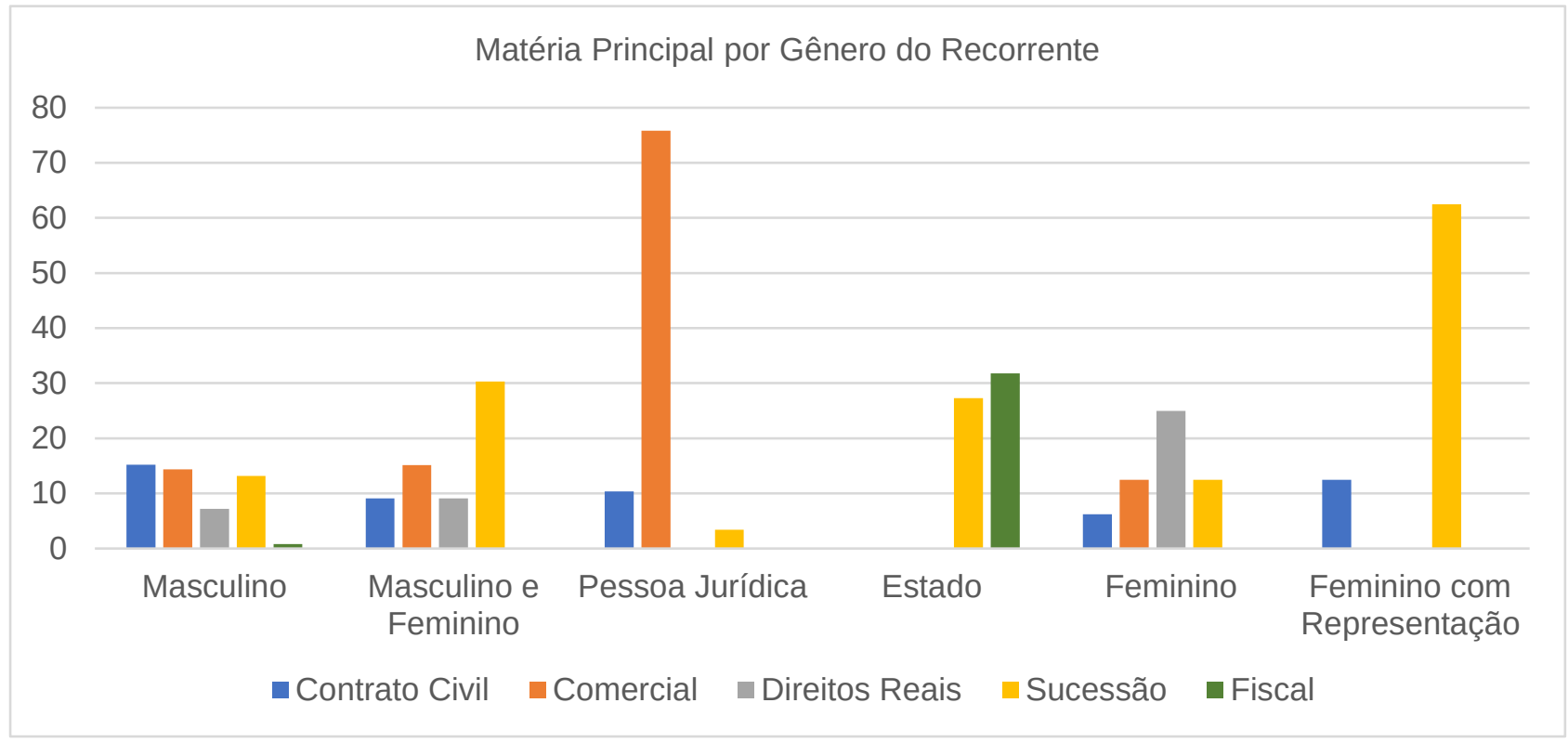

Na posição de recorrido o recorte de gênero indica tendências semelhantes, exceto por uma diferença importante: no polo passivo o Estado é alçado à segunda posição na proporção de recorridos (19,27\%), respondendo predominantemente a recursos em matéria criminal.

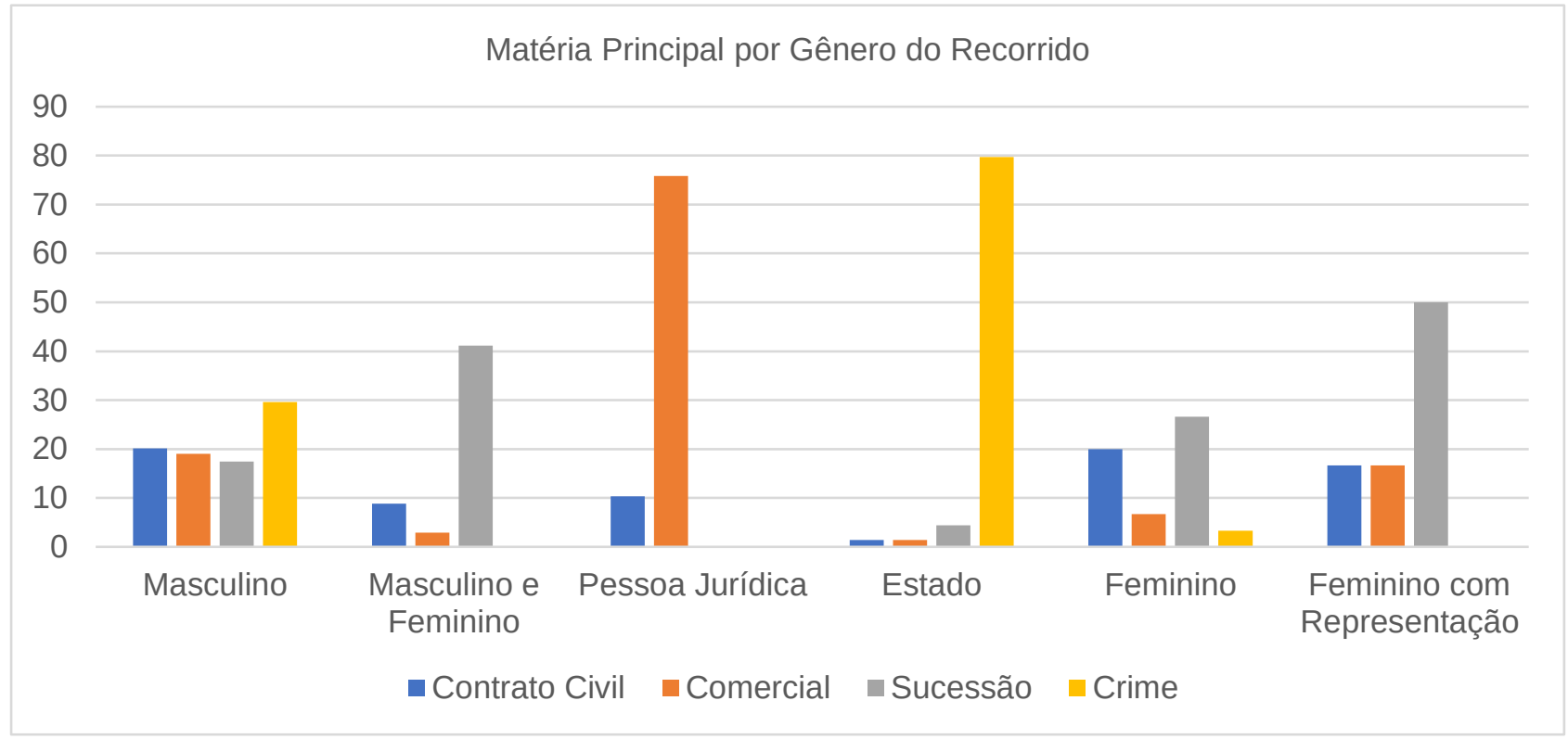

Como já havia sido mencionado, a falta de identificação do estatuto social da maior parte dos recorrentes dificulta a extração de resultados conclusivos a esse respeito (50,55\% dos recorrentes não tiveram o seu estatuto social identificado). A maior quantidade de recorrentes tem o seu estatuto social classificado de acordo com a natureza da ação, o que leva a resultados tautológicos. Ainda 
assim, é digna de nota a predominância de comerciantes (20,39\%, identificáveis pela origem e tema da ação) e do Estado (6,14\%, identificável pelo nome). As demais categorias são indicadas no gráfico abaixo por ordem de frequência.

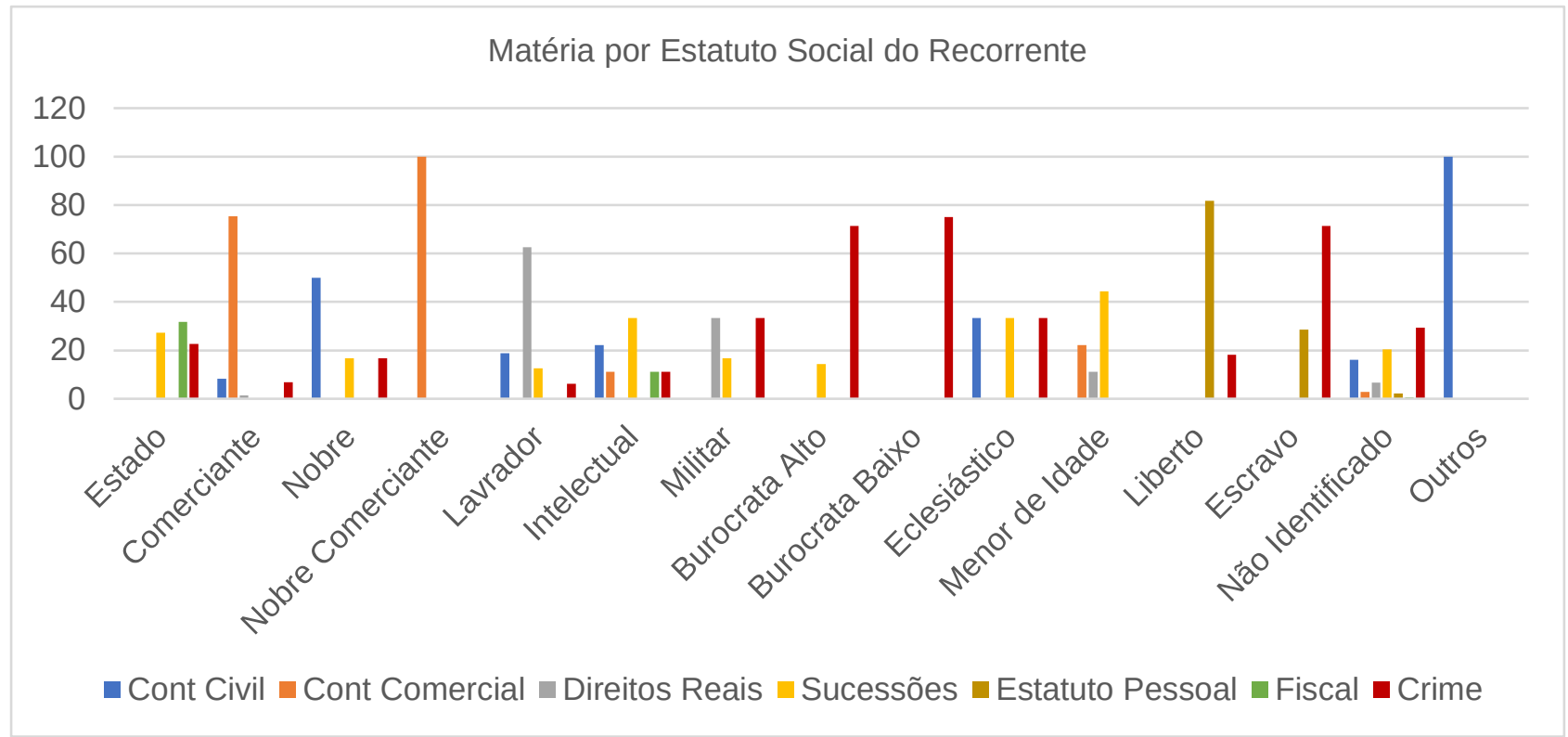

O mesmo vale para o estatuto social dos recorridos, observando-se distribuição semelhante de temas. A diferença marcante fica por conta dos escravizados, que recorrem predominantemente de matéria criminal, mas são recorridos principalmente quanto ao seu estatuto pessoal (liberdade); e dos libertos, que respondem por grande parte de recursos em matéria de sucessões (geralmente referentes à validade de alforrias testamentárias). 

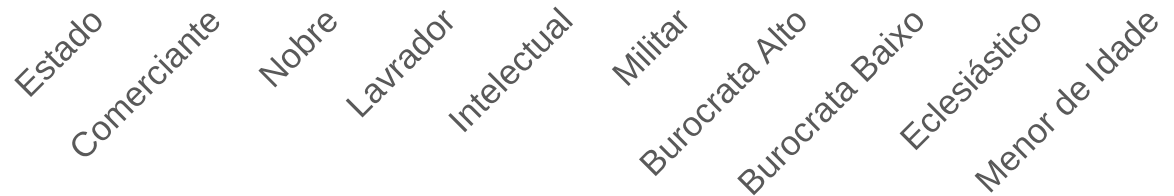

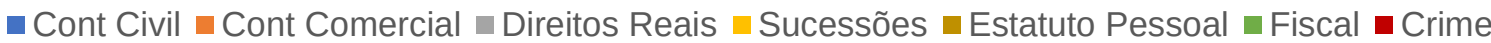

$\mathrm{Na}$ análise dos temas discutidos nos recursos interpostos observa-se a predominância de debates de natureza cível, seguidos por debates criminais e comerciais. Na fundamentação das decisões prolatadas predomina a legislação imperial, seguida da legislação colonial e da análise de fatos concretos. A tomada de fatos como elemento de fundamentação das decisões reitera a enorme abertura concedida ao STJ brasileiro para promover a reanálise do mérito e a valoração probatória em suas decisões de revista. Outras fontes de direito têm importância reduzida na fundamentação dos acórdãos. Quando se classifica a fundamentação empregada de acordo com o tema do recurso interposto se torna possível obter informações valiosas acerca da existência de fontes específicas para cada ramo do direito, a indicar o caráter transicional da ordem jurídica brasileira no período: a legislação imperial prevalece entre as matérias já codificadas no Brasil do século XIX, como o direito criminal e o direito comercial. A lei também é uma referência importante para o direito administrativo, pela própria natureza estatal de suas fontes normativas e pela novidade do regime jurídico peculiar. Já no direito civil, não codificado, prevalecem a lei colonial e os fatos concretos como fontes mais empregadas, e a lei imperial é relegada a uma distante terceira colocação. O recurso ao direito natural para decisões sobre liberdade e escravidão (57,14\%, incluídas na categoria direito civil) também é indicativo tanto do silêncio do legislador sobre o tema da escravidão, quanto dos debates teóricos acerca da liberdade no século XIX. 


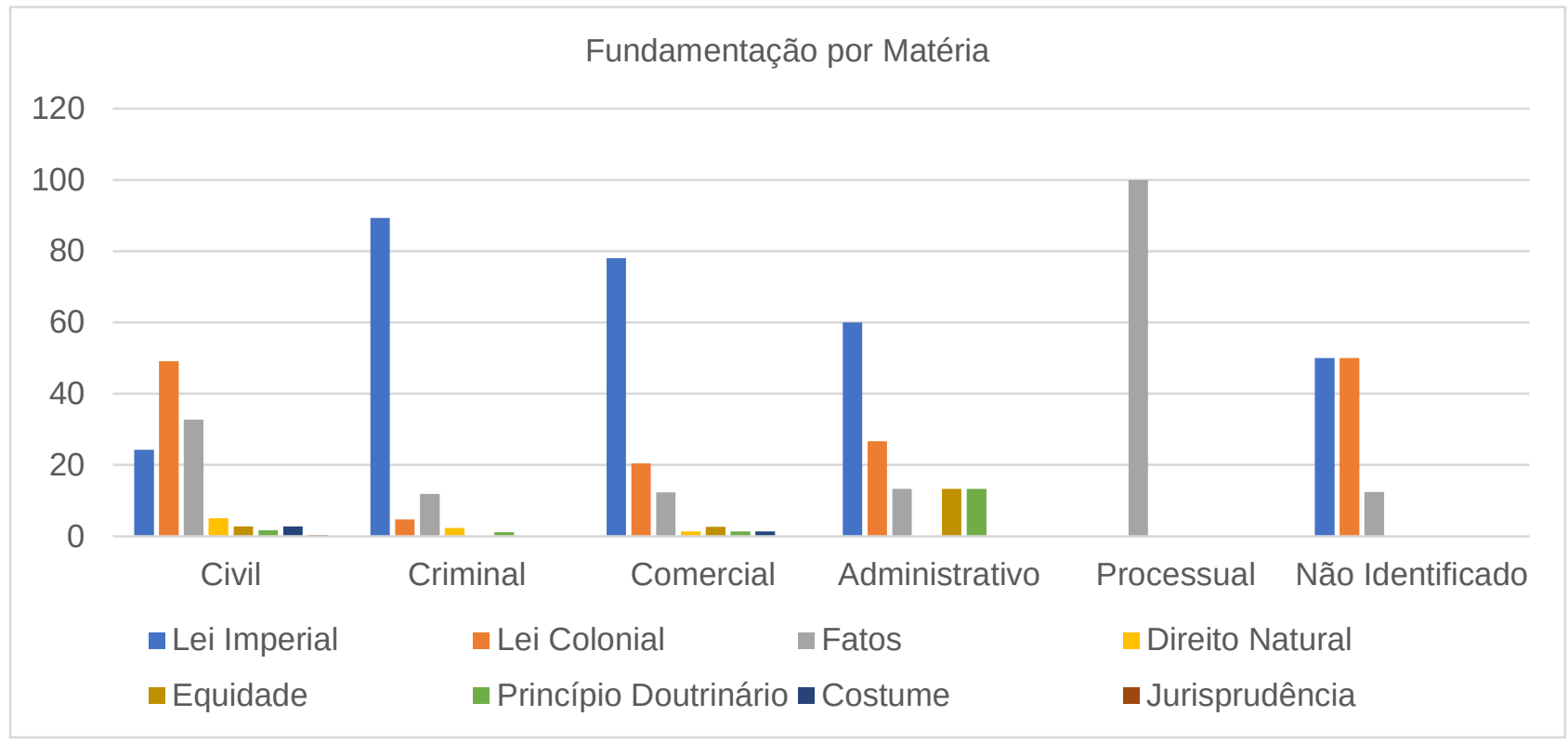

A análise diacrônica das decisões proferidas pelo STJ brasileiro também permite conclusões interessantes. Quanto ao gênero do recorrente, observa-se a predominância do gênero masculino durante todo o período estudado, sem qualquer modificação relevante na condição da mulher. Há, porém, um discreto crescimento dos recursos interpostos por pessoas jurídicas a partir de meados dos anos de 1860, talvez resultado do impulso propiciado pelo Código Comercial de 1850.

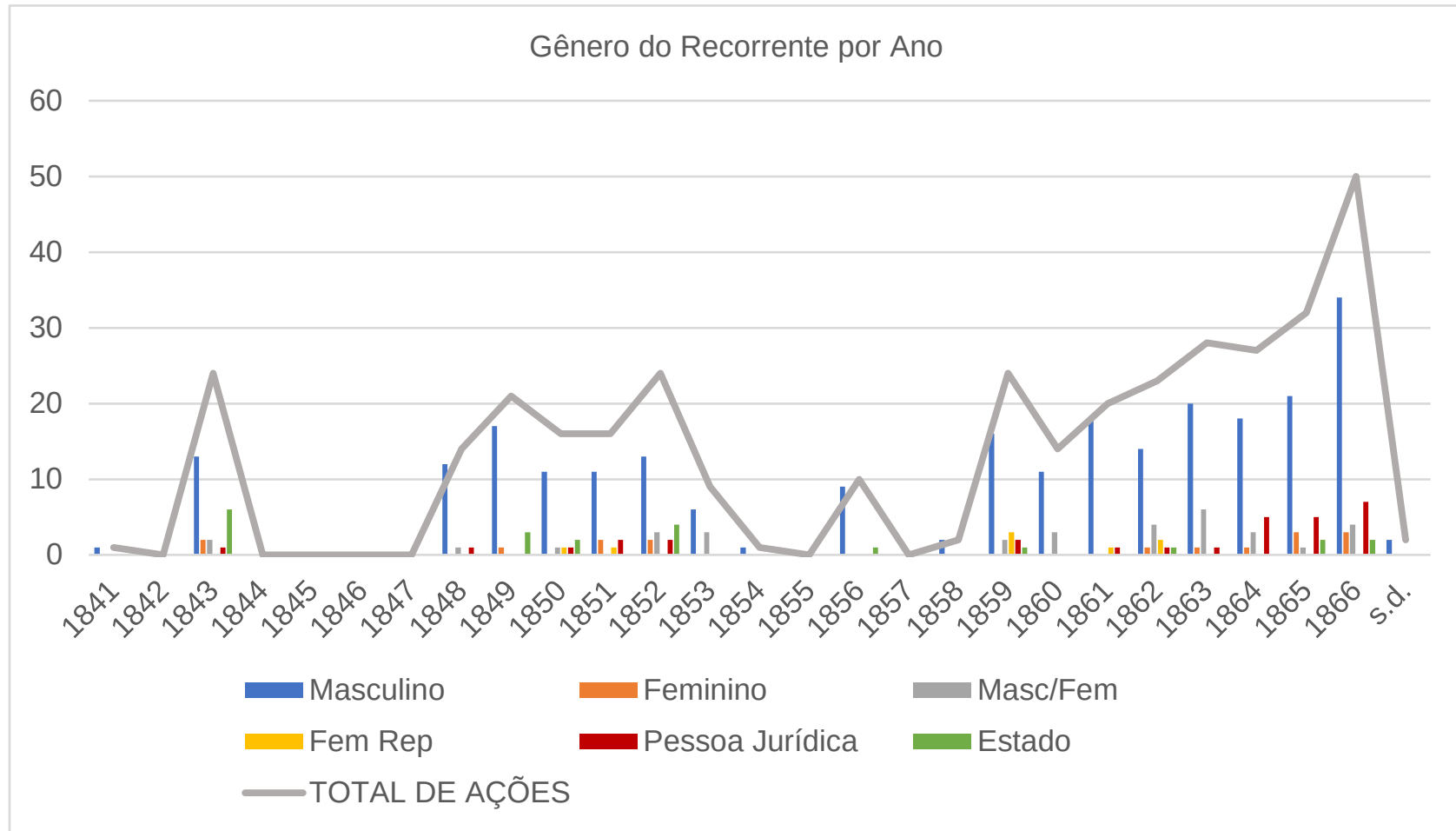


O mesmo ocorre quanto ao gênero do recorrido, observando-se, porém, um crescimento nos recursos interpostos contra o Estado, nomeadamente em matéria criminal e tributária. Os números talvez indiquem um esforço de disciplinarização da autoridade estatal, com o consequente aumento da intervenção fiscal e criminal do Estado sobre a vida social conforme se aproxima o final do século.

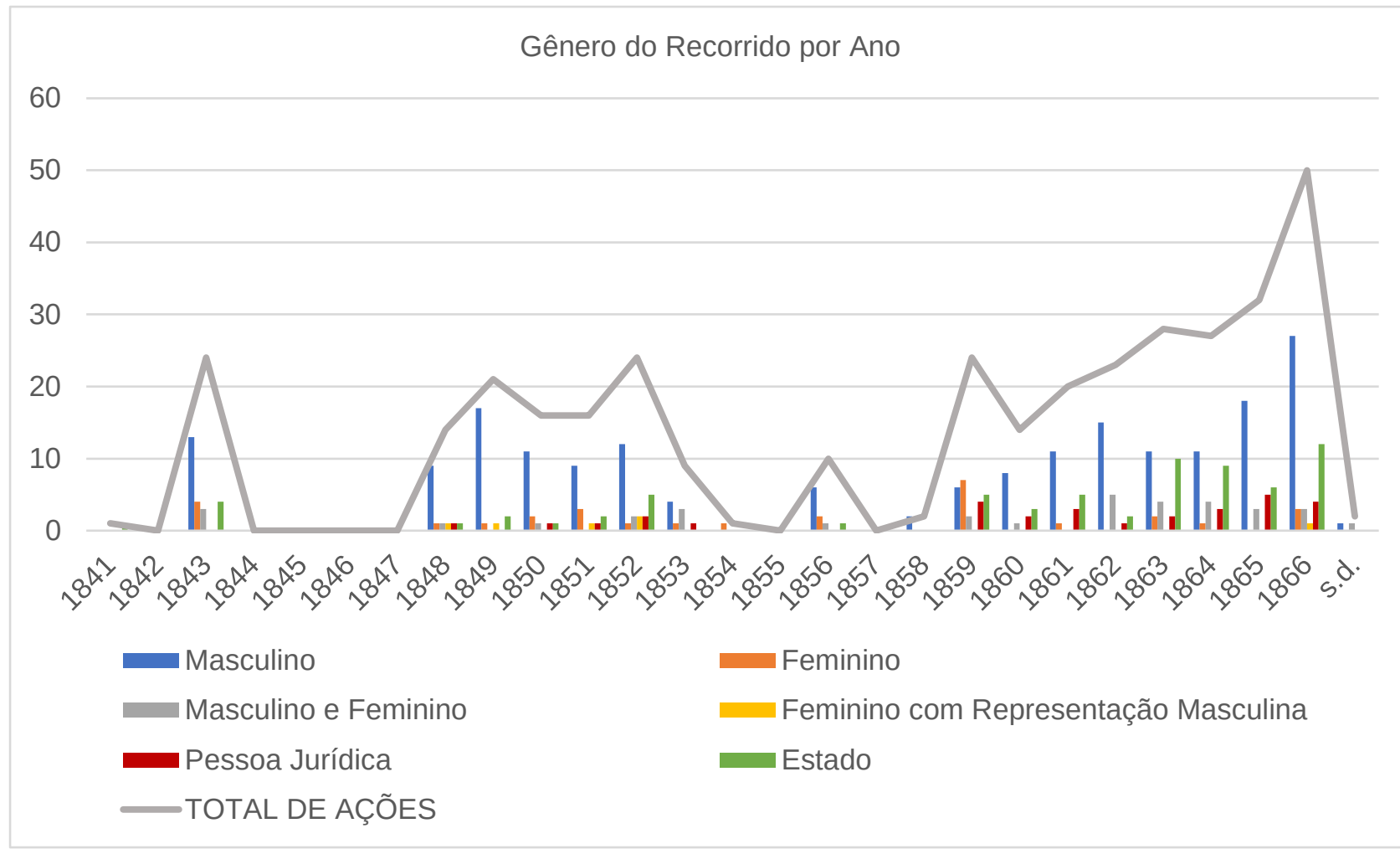

Quanto ao estatuto social, observa-se um crescimento notável da interposição de recursos por comerciantes a partir da década de 1850, certamente reflexo da nova codificação comercial. Também se verifica uma ligeira tendência de queda nos recursos interpostos por lavradores. Talvez o fenômeno reflita uma transformação mais geral na composição econômica da sociedade brasileira, lentamente transicionando de uma sociedade agrícola para uma sociedade comercial. Além disso, há um discreto aumento de recursos interpostos por escravizados e libertos a partir dos anos de 1860, provavelmente reflexo da nova legislação e do novo contexto social e político, tendente à abolição. 


\section{Estatuto Social do Recorrente por Ano}

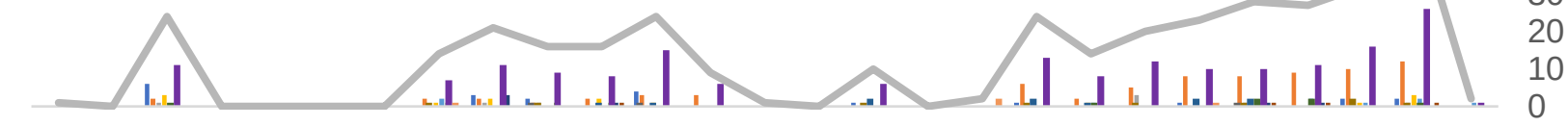

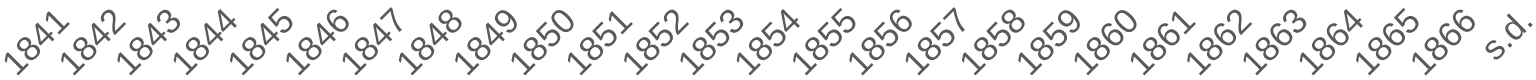

$\begin{array}{lcl}\text { Estado } & \text { Comerciante } & \text { Nobre } \\ \text { Lavrador } & \text { Intelectual } & \text { Militar } \\ \text { Burocrata Alto } & \text { Burocrata Baixo } & \text { Eclesiástico } \\ \text { Menor de Idade } & \text { Liberto } & \text { Escravo } \\ \text { Não Identificado } & \text { Outros } & \text { TOTAL DE AÇÕES }\end{array}$

O estatuto social do recorrido confirma as tendências verificadas:

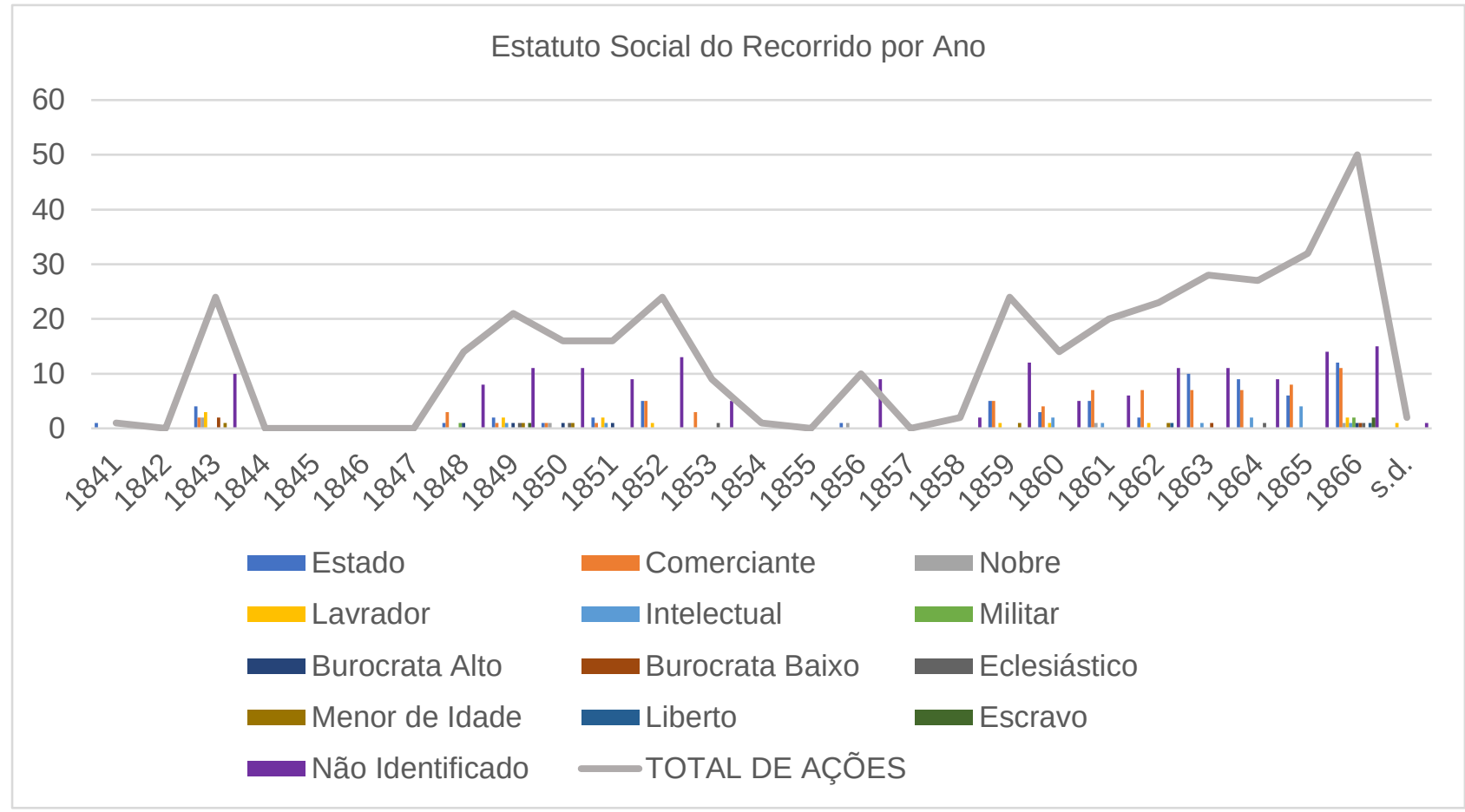

Quanto à matéria tratada nos recursos interpostos, mantém-se por todo o período a predominância de recursos de natureza cível. Observa-se, porém, o paulatino crescimento dos recursos em matéria criminal e comercial, especialmente a partir da década de 1860 - em alguns 
momentos até mesmo ultrapassando a quantidade de recursos cíveis interpostos (1863 e 1865). As demais matérias permanecem estáveis durante todo o período.

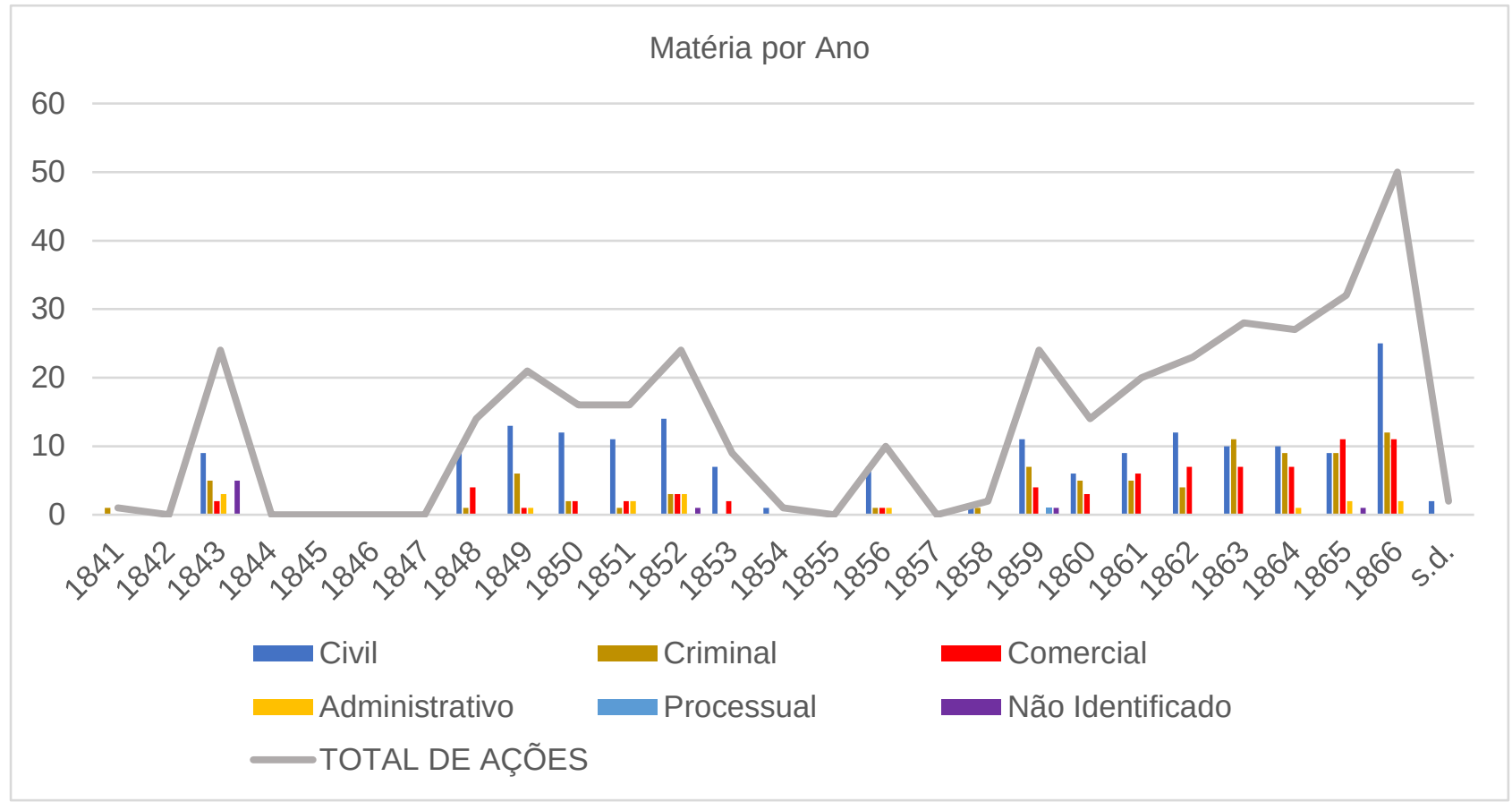

As matérias predominantes nos recursos interpostos impactam também na fundamentação predominantemente empregada nas decisões proferidas: observa-se o domínio constante da legislação imperial desde o início do período estudado, com um aumento progressivo até o final do século. A legislação colonial tem a sua importância reduzida a partir dos anos de 1850, mas retorna com mais vigor ao final do período. Seria necessário aprofundar o exame dos processos para avaliar as razões do fenômeno, aparentemente contraditório às tendências do período. Além disso, a fundamentação das sentenças tende a se tornar mais complexa com o passar do tempo, incorporando também princípios doutrinários e o julgamento por equidade, mas em percentual ainda insignificante. Observa-se também um aumento dos julgamentos pelo direito natural, que corresponde ao aumento nos julgamentos sobre estatuto pessoal (servidão e liberdade). O julgamento por fatos também perde a importância proporcional com o passar do tempo, e as decisões tendem a se fundamentar cada vez mais estritamente no direito positivo. 
60

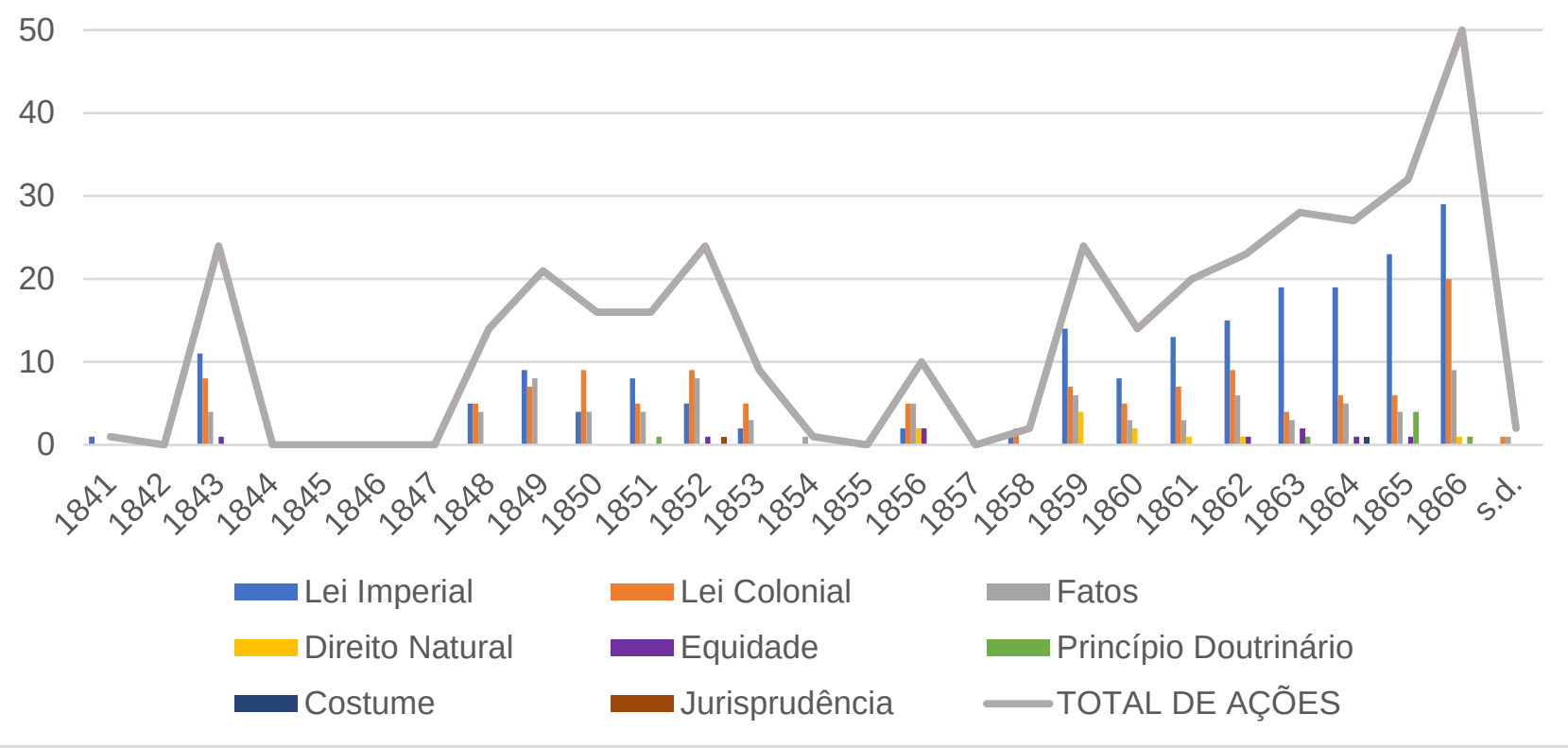

Os dados referentes às decisões proferidas pelo STJ português no período ainda não estão completos, mas os resultados preliminares obtidos já permitem uma análise comparativa com relação às decisões proferidas no Brasil. A principal diferença se refere à importância das questões de direito comercial no Brasil, diante da relativa desimportância da matéria em Portugal. Isto pode dever-se à maior litigiosidade dessa área no Brasil, à maior frequência de recursos ou à maior frequência de recursos do tipo dos conhecidos no STJ. Averiguar as duas primeiras hipóteses envolveria avaliar a importância relativa da atividade comercial, bem como os hábitos de litigância no grupo dos comerciantes portugueses e brasileiros.

No direito administrativo, nota-se um peso bastante maior das questões fiscais em Portugal - que, de fato, tinha um Estado fiscal mais organizado desde pelo menos o século XVII. Nos dois casos, os recursos de causas cíveis são mais frequentes do que os de causas crime. Também aqui se poderia supor que a publicação precoce de um código penal (1830) e de um código de processo penal (1832) no Brasil teriam tornado o direito mais firme e diminuído os casos de ilegalidade manifesta. Mas a confirmação destas hipóteses explicativas careceria de uma investigação mais fina dos casos recolhidos no banco de dados. 

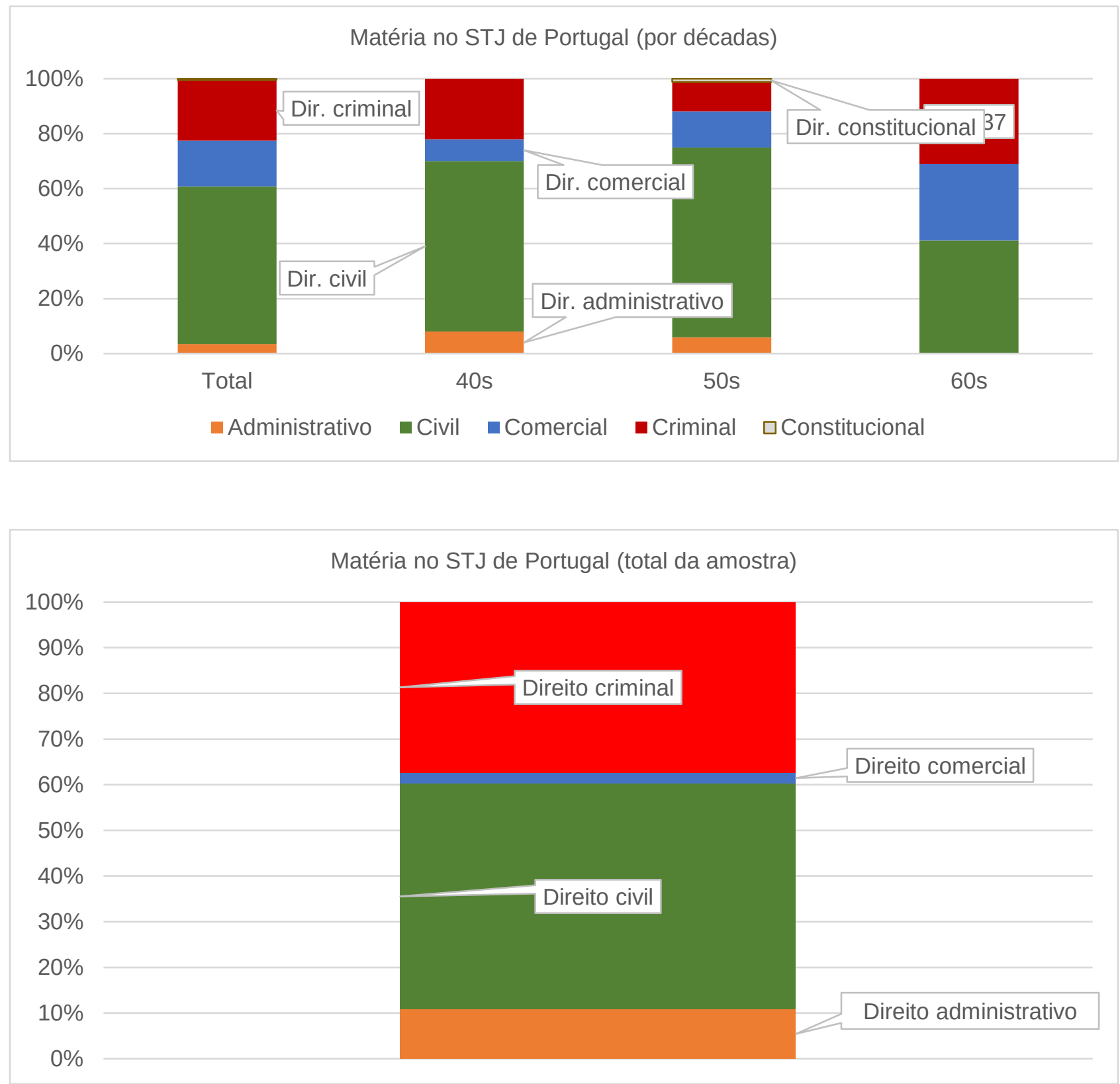

Avançando para uma análise mais detalhada, que considere os assuntos mais ocorrentes nas amostras, constroem-se os dois gráficos seguintes. Tanto no Brasil como em Portugal, ressalta-se o grande peso atribuído às questões de direito de família, sucessões e imobiliário, que correspondem a um percentual de 30\% a 40\% das decisões. Isso explica-se facilmente pelo fato de, nos dois países, estar-se perante sociedades fortemente estruturadas sobre as famílias e cuja fortuna era sobretudo agrária (ou, pelo menos, imobiliária). Mas a natureza desses recursos também aponta noutra direção, a da incerteza do direito, que facilitava decisões ilegais (em sentido lato) ou injustas, daquelas que o recurso de revista tentava clarificar. Tanto o direito de família como o direito de propriedade eram regulados pelo direito do antigo regime, em parte contido nas Ordenações, em parte no direito 
doutrinal. Nada disso foi substancialmente alterado até os códigos civis, que são posteriores à época estudada (1867 em Portugal, 1916 no Brasil). Uma hipótese a testar é a de que a diminuição dos recursos relativos à propriedade imobiliária no Brasil a partir de 1850 tenha algo a ver com a promulgação da Lei de Terras.

Além do direito comercial, também se observa no Brasil uma frequência maior de crimes de funcionários, certamente resultado da maior complexidade da estrutura administrativa brasileira. A relativa abundância de questões relacionadas a crimes políticos na amostra portuguesa se deve a vários casos relacionados a uma lei de anistia subsequente à paz de Évora Monte, no termo da guerra civil entre absolutistas e liberais.

Questões sobre escravos não existem em Portugal, embora a escravatura ainda existisse nas colônias (até 1869, embora no continente tivesse desaparecido durante o pombalismo). A menor incidência social do fenômeno e o uso desse tipo elitista de recurso explicam por que essas questões não apareçam no STJ português.

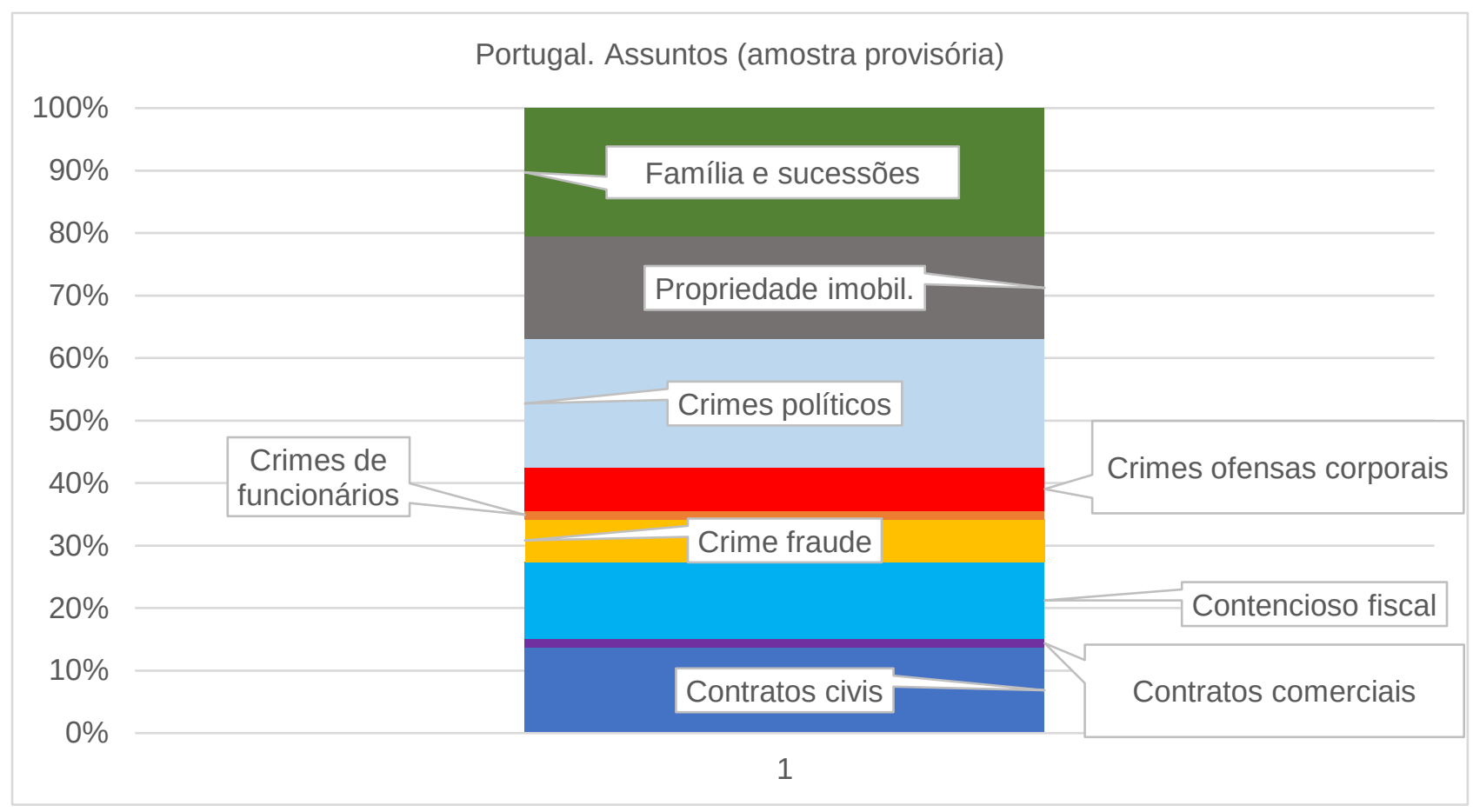

Sobre as questões mais próximas da motivação das sentenças, é possível adiantar algo, mas com bastantes cautelas. Primeiro, porque a motivação das sentenças de revista está intimamente relacionada ao regime desses recursos, muito vinculado ao controle da legalidade das decisões, embora com as aberturas já referidas para uma apreciação da “justiça” da decisão. Depois, porque havendo essa abertura para ponderar outros vícios que não a ilegalidade (má aplicação das normas 
abstratas aos casos concretos, má apreciação ou avaliação dos fatos), a distinção entre ilegalidade e injustiça é frequentemente pouco nítida - embrulhada ou eclética - no momento de fundamentar a concessão da revista, sobretudo se se comparar a fundamentação global com os concretos argumentos (rationes decidendi) invocados. De fato, é comum que no STJ brasileiro a ilegalidade também seja percebida como “injustiça”, e que a injustiça seja percebida como “ilegalidade”: não há preocupação dos julgadores em distinguir as duas hipóteses, que se confundem na prática. Qualquer descuido de interpretação do texto complica ainda mais as coisas.

Os gráficos abaixo dão conta do fundamento global do deferimento da revista nas duas amostras. No Brasil, ilegalidade e injustiça equiparam-se como fundamentos da decisão. Nuns poucos casos, os dois fundamentos aparecem invocados. Já se viu como isso se explica em face do regime mais aberto de admissibilidade do recurso de revista com qualquer um dos dois fundamentos. Em Portugal, pelo contrário, o regime do STJ era mais estritamente legalista quanto ao fundamento da revista. A ilegalidade era, em princípio, o único motivo para deferir o recurso, embora a doutrina tivesse um critério cada vez mais amplo de definição do que fosse "lei expressa". Por isso, os fundamentos invocados nos casos que fazem parte da amostra são, invariavelmente, a ilegalidade relativa ao direito processual ou ao direito substantivo. 


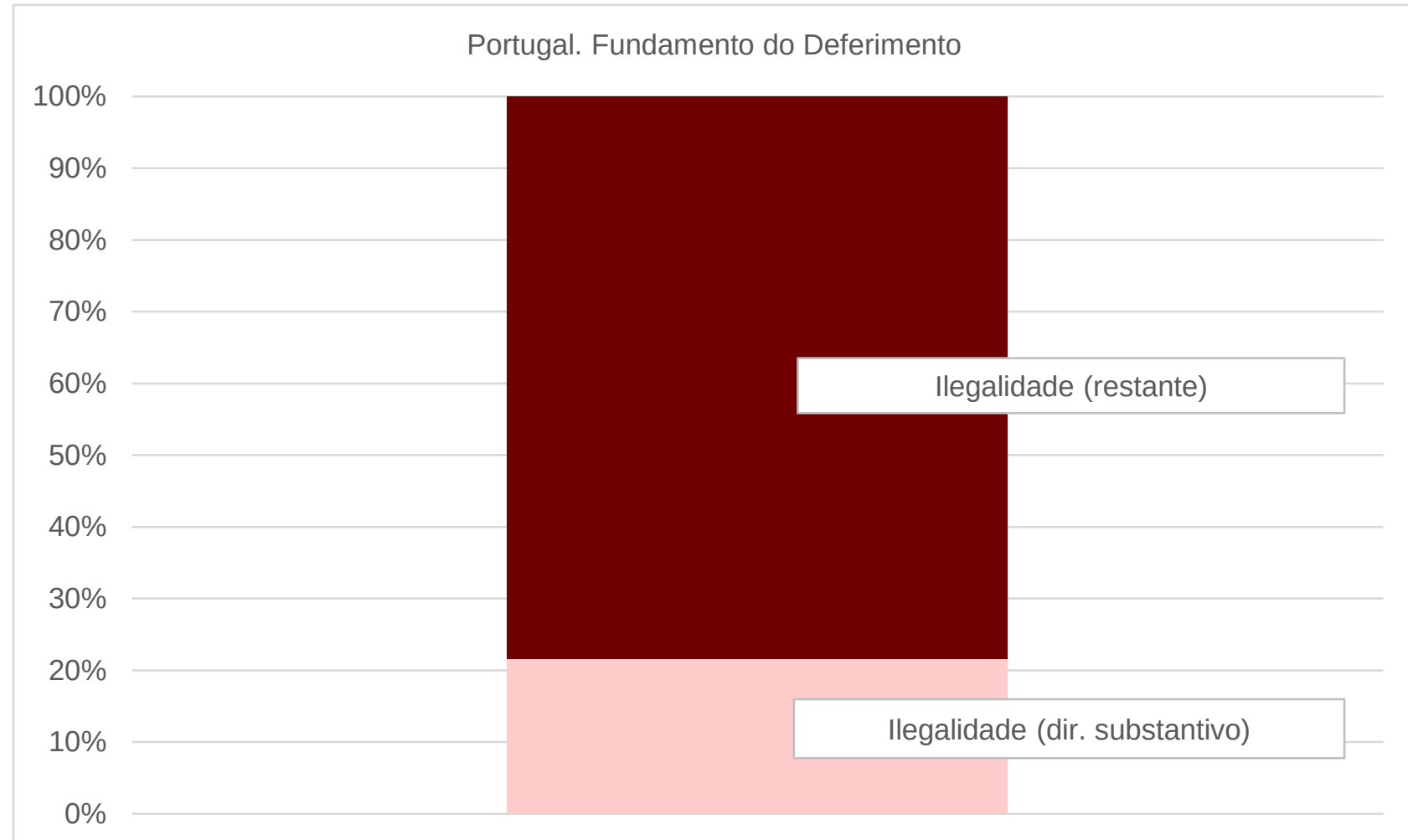

Entrando mais detalhadamente na análise das razões de decidir, a primeira constatação é a de que, muito frequentemente, as decisões são $\operatorname{curtas}^{38}$ e pouco detalhadas. Com todas as cautelas que devem ser tomadas quanto à classificação de cada decisão na tipologia adotada, verifica-se que, no 
Brasil, a dedução a partir da lei é a principal razão de decidir ao longo de todo o período, com tendência a consolidar-se. A decisão a partir dos fatos decorre da avaliação de provas do processo, e indica justamente a válvula de escape que permite a ampliação da competência do STJ no Brasil e a sua interferência mais ativa nas atividades de competência originária das Relações. A invocação de princípios é apenas residual, com o direito natural sendo empregado principalmente em casos que discutem o status de servos e libertos.

A amostra portuguesa produz resultados distintos, mas consistentes com algo que já se destacou antes: as decisões adotadas são tiradas quase exclusivamente da lei. Apesar de os progressos da codificação terem sido lentos (Código Comercial, 1833; Código Administrativo, 1841; Código Penal, 1852), a legislação invocada é, maioritariamente, a do período liberal; ou seja, em Portugal o STJ parece ter sido um instrumento mais eficaz de garantia do legalismo pós-revolucionário. Mas apenas uma análise diacrônica como a realizada para o STJ brasileiro permitirá avaliar melhor a natureza precisa desse "legalismo”. 


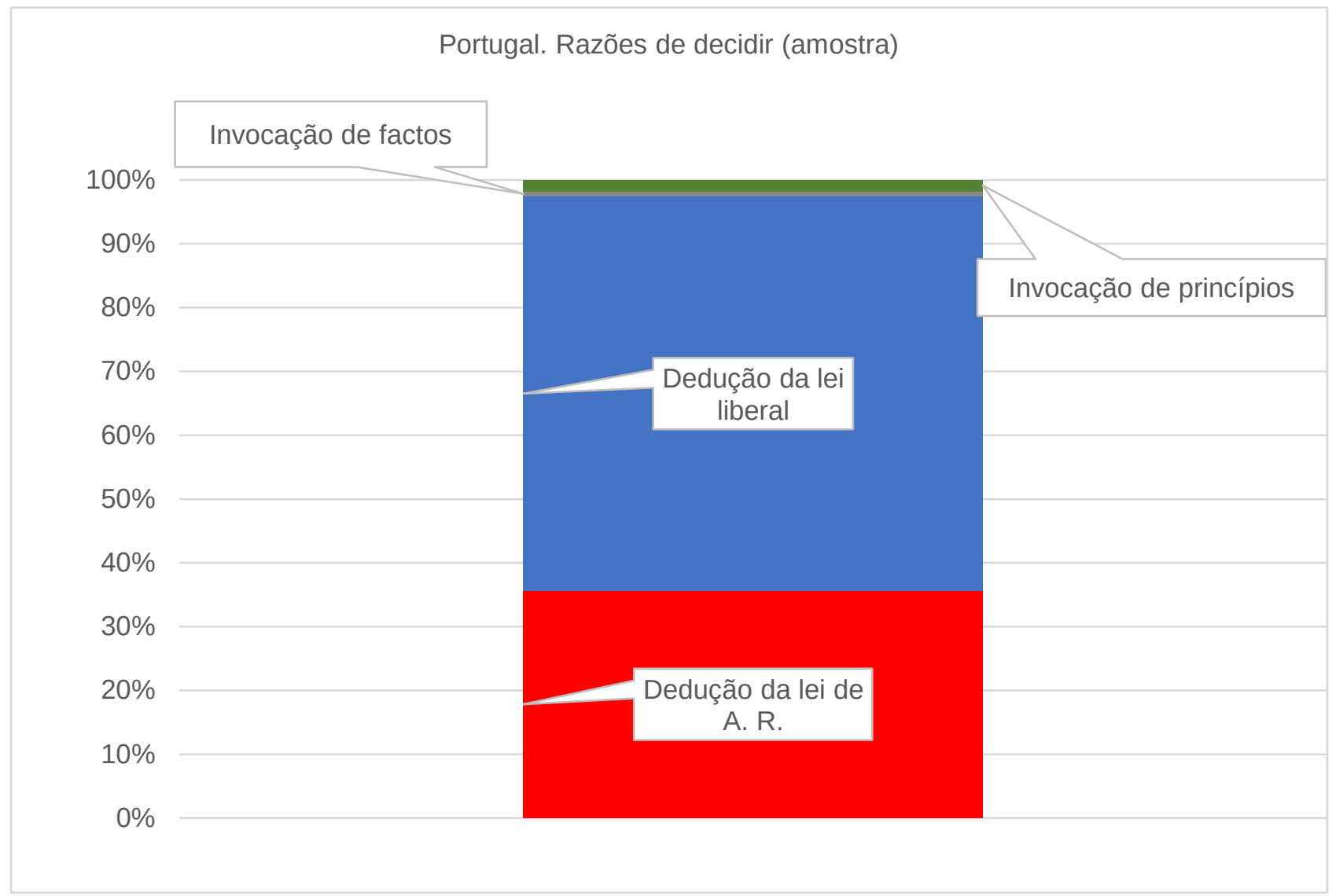

\section{REFERÊNCIAS}

Accursio, Francesco. “Glossa a C.7.45.12,” in Codicis D.N. Iustiniani sacratissimi principis, Imperatoris Augusti, Libri IX. Venetiis, 1592.

Aliste Santos, Tomás-Javier. La motivación de las resoluciones judiciales. Madrid-Barcelona: Marcial Pons, 2011.

Baldo degli Ubaldi. Commentaria in vi. vii. viii. ix. x. et xi. Codicis lib. Venetiis. 1572.

Barbosa, Manuel. Remissiones doctorum ad contractus, ultimas voluntates, et delicta spectantes in librum quartum, et quintum Ordinationum Regiarum Lusitanorum, cum concordantijs utriusque juris, legum partitarum, ac novae recopilationis Hispanorum, Ulyssipone: Ex officina Petri Craesbeeck (vols. 1 a 3: http://purl.pt/14212, 28.4.2014; vols. 4 e 5: http://purl.pt/14129, 14.01.2014), 1618.

Barros Corte Real, A. X. e Cardoso Castello Branco, J. M. (dir). Collecção dos accordaos que contêem materia legislativa proferidos pelo Supremo Tribunal de Justiça desde a epocha da sua instalação. Lisboa: Imprensa Nacional, 1859-1884.

Bártolo de Sassoferrato. In Primam Infortiati Partem. Venetiis, 1585. 
Beirão, Francisco António da Veiga. Organização judicial. Proposta apresentada à Câmara dos Senhores Deputados [...] pelo ministro e secretário de Estado dos negócios eclesiásticos e da justiça. Lisboa: Imprensa Nacional, 1887.

Biscotti, Barbara. "Dispositivo e parte motiva nella sentenza: idee vecchie e nuove," in Il giudice privato nel processo civile romano. Omaggio ad Alberto Burdese (Padova: CEDAM, 2012), 273331.

Cambanis, Vitale de. Aureus clausularum omnigenarum tractatus. Parisiis, 1515.

Caminha, Gregório Martins. Tratado da forma dos libelos, das alegações judiciais, do processo do juízo secular, e eclesiástico, e dos contratos, com suas glossas. Coimbra: Oficina dos Irmãos e Sobrinho Ginioux, 1746.

Castro, Pauli de. Clarissimi iuris utriusque doctoris Pauli Castrensis Commentariurum in codicem iustinianum pars secunda. Lugduni, 1544.

Costa, Afonso. Lições de organização judiciária. Coimbra, 1898.

De Luca, Giovanni Battista. Discorso dello stile legale cioè del modo col quale i professori della facoltà legale, cosi auvocati, e procuratori, come giudici, e consiglieri, \& anche i cattedratici, o lettori, debbano trattare in scritto, \& in voce delle materie giuridiche, giudiziali, \& estragiudiziali. Dell' eminentissimo cardinali de Luca, autore del teatro della verita et della giustitia. Colonia Allobrogum: J. A. Cramer, 1697.

Duarte Nazareth, Francisco. Elementos do processo civil. 4. ed. Coimbra: Augusto Orcel, 1866.

Ferraz, J. M. Commentario à lei de 19 de Maio de 1832, sobre a competência do Supremo Tribunal de Justiça. Lisboa, 1841.

Gil, Pedro Ortego. “Sentencias criminales en Castilla: entre jueces y abogados," in: Clio y crimen, $\mathrm{n}^{0} 10$ (Santiago de Compostella: Universidad de Santiago de Compostela, 2013), 359-372.

Gonçalves da Silva, Manuel. Commentaria ad Ordinationes Regni Portugalliae. Ulyssipone Occidentali, 1731.

Gorla, Gino. “La motivation des jugements,” in Foro italiano, 1979, V, col. 24, 1979.

Gorla, Gino. “Sulla via dei motivi delle sentenze: lacune e trappole,” in Foro italiano, 1980, V, col. 205 et seq.

Hespanha, António Manuel. "Os sentidos da motivação das sentenças na literatura jurídica prémoderna," in: O dever de fundamentação no novo CPC: análises em torno do artigo 489 (Fernando Andreoni e Tiago Gagliano Pinto, orgs.) (Rio de Janeiro: Lumen Juris, 2015a), 27-39.

Hespanha, António Manuel. Como os juristas viam o mundo. 1550-1750, Direitos, estados, pessoas, coisas, contratos, ações e crimes. Create Space-Amazon, 2015b. 
Hocks, Stephan. Gerichtsgeheimnis und Begründungszwang: zur Publizität der Entscheidungsgründe im Ancien Régime und im frühen 19. Jahrhundert. Frankfurt/Main: Vittorio Klostermann, 2002.

Lobão, Manoel de Almeida e Sousa de. Segundas Linhas sobre o Processo Civil, ou antes adições às Primeiras do Bacharel Joaquim José Caetano Pereira e Sousa. Lisboa: Imprensa Nacional, 1855.

Lopes Praça, José Joaquim. Estudos sobre a Carta Constitucional de 1826 e Acto Adicional de 1852. Coimbra: Imprensa Literaria, 1878.

Lorente, Marta e Garriga, Carlos. "El juez y la ley: la motivación de las sentencias (Castilla, 1489España, 1855)," in Anuario de la Facultad de Derecho de la Universidad Autónoma de Madrid, 1, 1997, 97-144.

Macedo, António de Sousa, Decisiones Supremi Senatus Justitiae Lusitaniae, \& supremi Consilij Fisci, ac patrimonij Regij, cum gravissimis Collegis decretae [...]. Ulyssipone: Henrici Valente de Oliveira, 1660.

Mafra, Manuel da Silva. Jurisprudência dos Tribunais, compilada os accórdãos dos tribunais superiores desde 1841. Rio de Janeiro: B. L. Garnier, 1867.

Melo Freire dos Reis, Pascoal José. Institutiones Iuris Civilis Lusitani. Coimbra: Typ. regalis Academiae scientiarum, 1789.

Mendes de Castro, Manuel. Practica lusitana, advocatis, judicibus, utroque foro quotidie versantibus admodum utilis, \& necessaria, in quinque libros divisa, cum ducentibus, et quadraginta novissimis Senatus Decisionibus, et centum contra cautellis. Olysipone: Georgium Rodericum, 1619.

Moraes de Carvalho, Alberto Antonio. Praxe Forense, ou Diretório Prático do Processo Civil Brasileiro conforme a atual legislação do império. Rio de Janeiro: Laemmert, 1850.

Oberto, Giacomo. La motivazione delle sentenze civili in europa: spunti storici e comparatistici. 2008. https://bit.ly/2xA1Jab.

Pegas, Manuel Álvares. Commentaria ad Ordinationes. Ulyssipone, 1729.

Pereira e Sousa, Joaquim José Caetano. Primeiras Linhas sobre o Processo Criminal. 3. ed. Lisboa: Tipografia Rollandiana, 1820.

Pereira e Sousa, Joaquim José Caetano. Primeiras Linhas sobre o Processo Civil. 4. ed. Lisboa: Imprensa Nacional, 1834.

Pereira, Bento. Promptuarium Juridicum. Ulyssipone: Typographia Dominici Carneiro, 1664.

Pimenta Bueno, José António. Apontamentos sobre as Formalidades do Processo Civil. Rio de Janeiro: Typographia Nacional, 1858. 
Pimenta Bueno, José António. Direito publico brasileiro e analyse da Constituição do Império. Rio de Janeiro: Typ. Imp. e Const. de J. Villeneuve e Comp., 1857.

Portugal, Domingos Antunes. Tractatus de donationibus regiis. Ulyssipone: Ioannis Costa, 1699.

Ranieri, Filippo. El estilo judicial español y su influencia en la Europa del Antiguo Régimen, Antonio Pérez Martín, España y Europa, un pasado jurídico común. Actas del I Simposio Internacional del Instituto de Derecho Común, Murcia, 1986, 101-118.

Reis, José Alberto dos. Organização judicial - Lições feitas ao curso do $4^{\circ}$ ano Jurídico de 1908 a 1909. Coimbra: Imprensa Acadêmica, 1909.

Ribas, Antonio Joaquim. Consolidação das Leis do Processo Civil. Rio de Janeiro: Dias da Silva Junior, 1879.

Sá, Eduardo Dally Alves de. Supremo Tribunal de Justiça. Evolução histórica d'esta instituição e apreciação da sua essencia e modo de ser actual. Estudo sobre a cassação e o tribunal das revistas em Portugal. Lisboa: Imprensa Nacional, 1872.

Scholz, Johannes-Michael. "Motiva sunt pars sententiae. Urteilsbegründung in Aragon (16.-18. Jahrhundert)," in La formazione storica del diritto moderno in Europa (Bruno Paradisi, org.). Firenze: Olschki, 1977, vol. II, 581-598.

Slemian, Andréa. “As monarquias constitucionais e a justiça, de Cádis ao Novo Mundo: o caso da motivação das sentenças no Império do Brasil (c.1822-1850)”. Dimensões, v. 39, jul.-dez. 2017, 1751.

Taruffo, M. “La motivazione della sentenza civile tra diritto comune e iluminismo,” in: Rivista di Diritto Processuale, 1974, 279 et seq.

Tomás, Manuel Fernandes. Repertório geral, ou índice alphabetico das leis extravagantes do Reino de Portugal. Coimbra: Real Imprensa da Universidade, 1815-1819.

Valasco, Alvaro. Decisiones consultationum ac rerum judicatarum in regno Lusitaniae. Ulyssipone: B. Albinum, 1597.

Valasco, Thomé. Allegationes super varias materias. Ulyssipone: Sumptibus Francisci de Sousa \& Antonij Leite Pereyra, 1679.

Velasco, Gabriel Alvarez. Judex perfectus seu de judice perfecto [...]. Lugduni: Horatio Boissat, 1612.

Villar, Alfonso Murillo. “Antecedentes históricos de la obligación de motivar las decisiones judiciales en el derecho español," in Teoria e Storia del Diritto Privato (Rivista Internazionale di Diritto Privato), 5, 2012. 
António Manuel Hespanha

Licenciado e Pós-Graduado em Ciências Histórico-Jurídicas pela Universidade de Coimbra. Professor catedrático jubilado na Faculdade de Direito da Universidade Nova de Lisboa. Investigador Honorário no Instituto de Ciências Sociais da Universidade de Lisboa. Membro correspondente do Instituto Histórico-Geográfico Brasileiro e do Instituto de Investigaciones de Historia del Derecho. Doutor honoris causa pela Universidade de Lucerna e pela Universidade Federal do Paraná.E-mail: amhmeister@gmail.com

Walter Guandalini Junior Mestre e Doutor em Direito do Estado pela Universidade Federal do Paraná, com estágio de pesquisa doutoral no Centro di Studi per la Storia del Pensiero Giuridico Moderno (Università degli Studi di Firenze). Professor na Faculdade de Direito da Universidade Federal do Paraná e no Mestrado em Direito do Centro Universitário Internacional. Membro do Instituto Brasileiro de História do Direito e do Instituto Latino Americano de Historia del Derecho. Advogado na Companhia Paranaense de Energia. E-mail: prof.walter.g@gmail.com 